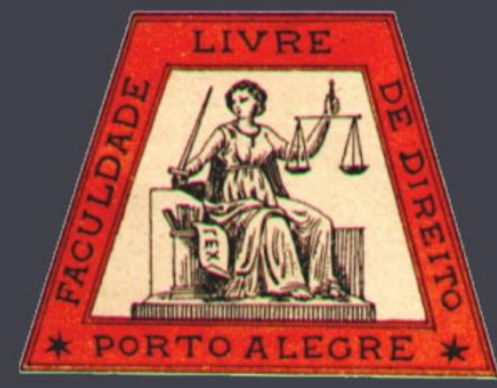

\title{
O poder do chefe de Estado e de Governo brasileiro no recorte histórico do Segundo Reinado
}

The power of the Brazilian head of State and of Government in the historical period of the Second Reign

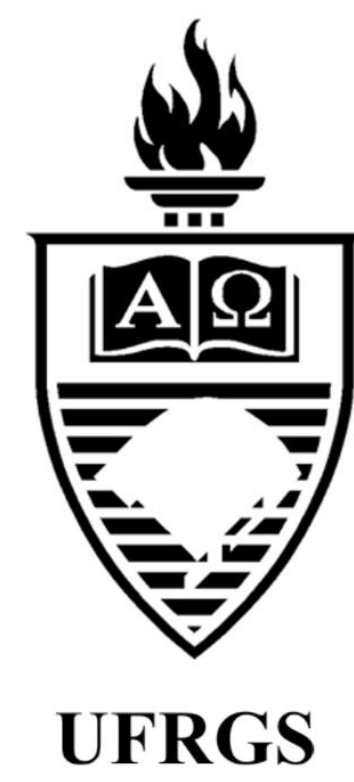

Andrea Regina Morais Benedetti Universidade Estadual do Oeste do Paraná

\section{Eduardo Caetano Tomazoni}

Universidade Estadual do Oeste do Paraná 


\title{
O poder do chefe de Estado e de Governo brasileiro no recorte histórico do Segundo Reinado
}

\author{
The power of the Brazilian head of State and Government in the historical period of the Second \\ Reign
}

\author{
Andrea Regina Morais Benedetti *
}

Eduardo Caetano Tomazoni ${ }^{* *}$

\section{REFERÊNCIA}

BENEDETTI, Andrea Regina Morais; TOMAZONI, Eduardo Caetano. O poder do chefe de Estado e de Governo brasileiro no recorte histórico do Segundo Reinado. Revista da Faculdade de Direito da UFRGS, Porto Alegre, n. 35, vol. esp., p. 50-76, dez. 2016.

\section{RESUMO}

$\mathrm{O}$ artigo analisa a proposta da Monarquia Parlamentarista no Brasil, a partir de uma análise da Constituição Imperial de 1824, especificamente no que concerne aos poderes do chefe de Estado e de Governo por ela designados. E, ainda, dos poderes exercidos de facto pelo Imperador. Para tanto, situa brevemente o momento histórico estudado e delimita importantes fundamentos jurídicos e filosóficos da Constituição de 1824. Na sequência, analisa o chamado parlamentarismo às avessas brasileiro, ante ao grau de utilização dos poderes conferidos ao monarca durante o Segundo Reinado. A opção metodológica escolhida foi, de modo indutivo e utilizando técnicas de estudos bibliográficos, dar enfoque aos atos realizados por meio do Poder Moderador e à estabilidade política conferida ao regime do Segundo Reinado, por tal poder. $\mathrm{O}$ resultado obtido foi o de que o período monárquico foi um dos (senão o) períodos mais politicamente estáveis deste país, instaurando um sistema Parlamentarista que era adaptado à realidade brasileira da época.

\section{PALAVRAS-CHAVE}

Brasil Império. Constituição de 1824. Poder Moderador. Equilíbrio entre poderes. Parlamentarismo às Avessas.

\begin{abstract}
This paper analyzes the proposal of the Constitutional Monarchy in Brazil, based on an analysis of the Brazilian 1824 Imperial Constitution, specifically regarding the powers of the head of State and Government designated by it and the powers exercised de facto by the Emperor. For the analysis, there is a brief introduction on the historical moment studied, as well as an explanation about important juridical and philosophical foundations of the 1824 Constitution. Thereafter, it analyzes the socalled Brazilian "Parlamentarismo às Avessas" (reverse parliamentarism), in view of the degree of utilization of the powers conferred on the monarch during the Brazilian Second Reign. The methodological option, in an inductive way and using techniques of bibliographic studies, to focus on the acts performed through the Moderative Power and the political stability conferred to the Brazilian Second Reign by such power. The result obtained was that the Second Reign period was one of the (if not the most) politically stable periods in this country, establishing a parliamentary system adapted to the Brazilian reality of that time.
\end{abstract}

\section{KEYWORDS}

Empire of Brazil. Brazilian 1824 Constitution. Moderative Power. Balance of Powers. Reverse Parliamentarism.

\section{SUMÁRIO}

Introdução. 1. A Constituição de 1824 e o Sistema Representativo. Fundamentos, características, a tetrapartição dos poderes. 2. O Parlamentarismo às avessas e o grau de utilização dos poderes conferidos ao monarca durante o Segundo

\footnotetext{
* Doutora em Direito pela Universidade Federal do Paraná (2016). Mestre em Direito pela Pontifícia Universidade Católica do Paraná (2011). Possui graduação em Direito pela Faculdade de Direito de Curitiba (1998). Docente Efetiva do Curso de Direito da Universidade Estadual do Oeste do Paraná - UNIOESTE.

** Graduando na Universidade do Oeste do Paraná - UNIOESTE.
} 
Reinado. Considerações finais. Referências.

\section{INTRODUÇÃO}

Em 07 de setembro de 1822, o então príncipe Dom Pedro de Alcântara, em viagem na província de São Paulo, declarou a secessão brasileira do Reino Unido de Portugal, Brasil e Algarves. Seguiu-se a Guerra de Independência, que culminou no Tratado do Rio de Janeiro de 1825 , onde Portugal reconheceu a independência brasileira.

Declarada a independência, em 12 de outubro de 1822 o príncipe foi coroado "Sua Majestade Imperial, Dom Pedro I, Imperador Constitucional e Defensor Perpétuo do Brasil", mas o cabo-de-guerra entre o então Imperador e o Congresso Nacional de imediato se instalou ${ }^{1}$.

Era necessário, então, produzir um códex que guiasse a nação e satisfizesse os anseios políticos do povo e das elites, sendo, para este fim, instalada a primeira Assembleia Nacional em 03 de maio de 1823. Nesse meio tempo, desde a independência e enquanto a Assembleia estava ocupada com os debates da elaboração da Constituição, a Coroa tomou as rédeas da nação, realizando atos sem prestar contas à Assembleia, como, por exemplo, definindo a nova bandeira nacional, conforme Oliveira Lima (1921, p. 314): "Prosseguira entrementes o governo imperial a cercar-se dos atributos da soberania". E nesse passo, em "10 de novembro era o corpo diplomático estrangeiro na capital notificado da

\footnotetext{
1 "A crise política começou, pois, verdadeiramente, na ocasião da aclamação, ou melhor, começara poucos dias antes da solenidade, pretendendo a facção democrática cercear a autoridade imperial no próprio momento em que ela era conferida, o que só não tentou realizar porque o Príncipe e seu ministro, sabedores de suas intenções, tomaram precauções para tolhê-las e iludir semelhante propósito. A questão era de quem predominaria - o soberano ou a assembléia, a coroa ou a constituição?" Em LIMA, 1921, p. 303.
}

adoção da bandeira e do tope do Brasil, sem que entretanto the houvesse sido previamente participada oficialmente a aclamação (LIMA, 1921, p. 314)."

Grande parte das deliberações da Assembleia concernia, justamente, em definir o papel dos poderes Executivo, Legislativo e Judiciário, e qual seria o papel da Coroa no Estado. O anteprojeto limitava fortemente os poderes do monarca, que passaria a ter um papel meramente figurativo. Dom Pedro I, insatisfeito com isto ${ }^{2}$, baixou o Decreto de 12 de Novembro de 1823, determinando a dissolução da Assembleia, e convocando no mesmo ato outro corpo $^{3}$ de pessoas para trabalharem na futura constituição, que seria "duplicadamente mais liberal, do que a extinta assembléia acabou de fazer" (BRASIL, 1823).

O novo corpo deliberativo, escolhido pelo Imperador, tomou por base os trabalhos realizados até então pela Assembleia Nacional, completando-o e modificando-o, conforme as orientações fornecidas por Dom Pedro I. Sendo assim, em 25 de março de 1824, a carta foi

\footnotetext{
2 "Certamente teriam concorrido para o golpe algumas disposições da Constituinte como a que dispunha que ' $\mathrm{O}$ corpo Legislativo não poderá ser dissolvido pelo rei', além de subordinar as forças armadas ao Parlamento e não ao Imperador, o que o indignava e aos seus aliados militares, e, finalmente, a restrição que o Projeto imporia ao exercício imperial do veto, que seria apenas suspensivo, o que, na verdade, não aconteceu." Em CERQUEIRA, 1997, p. 37.

${ }^{3}$ Tal corpo tratava-se do segundo Conselho de Estado brasileiro, que em 15 dias finalizou a nova Constituição. $\mathrm{O}$ Conselho era composto por dez membros, além dos ministros de Estado (todos brasileiros natos) dentre os quais estavam José Joaquim Carneiro de Campos, primeiro Marquês de Caravelas, principal redator da Carta e defensor ferrenho do Poder Moderador, José Egídio Álvares de Almeida, marquês de Santo Amaro, presidente da Assembleia Constituinte dissolvida por Dom Pedro I e Luís José de Carvalho e Melo, primeiro Visconde com grandeza de Cachoeira, signatário do Tratado do Rio de Janeiro de 1825, dentre outros.
} 
outorgada e o Brasil adotava sua primeira Constituição como nação independente.

Em 7 de abril de 1831, Dom Pedro I abdicava da Coroa brasileira, iniciando-se o período da Regência, extremamente conturbado para a nação, onde o Império noviço quase ruiu com as diversas insurgências regionais (LIMA, 1921, p. 340). Tal instabilidade resultou na reação de 23 de julho de 1840, a Declaração da Maioridade de Dom Pedro II, dando início ao Segundo Reinado, que acabaria no coup d'etat de 15 de novembro de 1889 .

Dom Pedro II, o monarca do Segundo Reinado, é frequentemente citado como um dos mais marcantes governantes que o Brasil já teve, estando firmemente marcado no imaginário da história nacional, e é frequentemente lembrado de forma saudosista, seja no meio acadêmico, político ou midiático. A proposta da Monarquia Parlamentarista, por outro lado, é motivo de chacota ${ }^{4}$ no Brasil. E dois dos maiores argumentos contra essa proposta são, de um lado, de que é um regime inútil, pois o monarca teria um papel meramente figurativo, sem poder, e, do outro lado, de que o monarca concentraria um poder demasiadamente grande em suas mãos, não sendo melhor do que qualquer ditadura existente no globo.

Assim, este artigo objetiva contribuir para o debate sobre a proposta da Monarquia Parlamentarista no Brasil, a partir de uma análise da Constituição Imperial de 1824, especificamente no que concerne aos poderes do chefe de Estado e de Governo por ela designados. E, ainda, dos poderes exercidos de facto pelo Imperador. A opção metodológica

\footnotetext{
${ }^{4}$ Coincidentemente ou não, a maioria dos estudos robustos sobre o Parlamentarismo Monárquico provém dos países que ainda mantém tais sistemas. Sendo assim, para a leitura de uma análise da proposta monárquica pelo seu viés econômico, ver 'Democracia: o Deus que falhou' de Hans-Hermann Hoppe, e do Parlamentarismo Monárquico, ver o artigo 'Consideraciones acerca de la utilidad y vigencia de la institución monárquica', de Amadeo Martín Rey Cabieses. Ver referências.
}

escolhida foi dar enfoque aos atos realizados por meio do Poder Moderador e à estabilidade política conferida ao regime do Segundo Reinado, por tal poder. Isso porque o período monárquico foi o de maior estabilidade política que o Brasil já teve (44 anos ininterruptos a partir do fim da Guerra dos Farrapos, de 1845 1889), merecendo detida reflexão.

\section{A CONSTITUIÇÃO DE 1824 E SISTEMA REPRESENTATIVO: FUNDAMENTOS, CARACTERÍSTICAS E A TETRAPARTIÇÃO DOS PODERES}

Conforme já referido, o Imperador Dom Pedro I, após dissolver a Assembleia Constituinte, nomeou um conselho para elaborar a constituição política do Brasil, resultando na outorga, em 25 de março de 1824, da "Constituição Política do Império do Brazil". Tal ato culminou numa grande crítica a Dom Pedro I, que foi taxado de absolutista, dando início aos atritos que culminariam com sua abdicação, em 1831.

A Constituição Imperial foi, em grande parte, influenciada pelas experiências provenientes da França, da Espanha, de Portugal e do Reino Unido ${ }^{5}$, à época. Quanto à inspiração francesa, o Corpo nomeado por Dom Pedro I inspirou-se nas ideias de Benjamin Constant e na Carta de 1814 (que restaurou a dinastia de Bourbon na França), no sentido de se desenvolver, ou melhor, positivar, um poder que agisse de árbitro, saneando e moderando os atritos que surgiam da tripartição, inspirada em Montesquieu, dos poderes Executivo (exercido pelo Rei), Legislativo (exercido pelo parlamento) e Judiciário.

\footnotetext{
5 “[...] o Império luso se inclinou naturalmente para o exemplo inglês, seja diretamente no seu direito parlamentar costumeiro, seja indiretamente, no direito escrito, através da Monarquia parlamentar francesa, ela própria provinda de além-mancha." Em FRANCO, 1957, p. 226.
} 
Tal inspiração, que resultou na positivação do Poder Moderador, será analisada em tópico próprio, mas é importante ressaltar que a França desta época estava se recuperando de um período extremamente conturbado, decorrente da Revolução Francesa, Reino de Terror, Diretório, Império Napoleônico, onde houve muitos abusos dos poderes, resultando numa instabilidade gigantesca no país. A inspiração fica mais clara quando se analisam os artigos da Carta francesa, conforme Mello Filho (2014, p. 64):

O poder moderador, privativo do monarca e exclusividade da instituição imperial brasileira, tem influência externa visível, tomando como exemplo o artigo 99 da constituição imperial brasileira que copia da constituição francesa de 1814 as expressões "sagrada e inviolável”, para se referir ao status jurídico de seu monarca, mais precisamente do artigo 13 da mesma.

Quanto à inspiração britânica, esta se deu pela característica do sistema jurídicoconstitucional britânico, o Common Law, que, com a evolução da sociedade e do Estado britânico, desenvolveu o seu sistema parlamentar, tornando-se, na época, o modelo liberal a ser seguido pelas monarquias parlamentaristas, vez que é um sistema que confere ao Monarca poderes para enfrentar crises ou moderar atritos (ex: dissolução do parlamento, demissão do primeiro-ministro), mas que também limita fortemente a atuação do Monarca nessas ocasiões, por força do costume.

Juntamente com a inspiração francesa, tem-se a inspiração espanhola, que vem da Constituição de Cádiz, datada de 1812. Afirma Feloniuk (2015, p. 2) que "apesar da atenção outorgada não ser costumeiramente grande, a Constituição de Cádiz é provavelmente a segunda maior fonte de influência estrangeira sobre o constitucionalismo nascente no Brasil em 1820." A Espanha dessa época encontrava-se numa situação delicada, por conta da invasão napoleônica e a consequente guerra de resistência espanhola. Convocadas as Cortes Gerais pela Junta Suprema Central, opositora do regime bonapartista, estas se reuniram na cidade de Cádiz na data 24 de setembro de 1810, e promulgaram em 19 de março de 1812 a "Constituição Política da Monarquia Espanhola", que ficou conhecida como a Constituição de Cádiz.

Essa Constituição teve grande influência "[...] sobre os direitos, a divisão de poderes, a família imperial e a organização territorial do poder. Ao longo de toda a norma brasileira podem ser encontrados vestígios da norma espanhola [...]" (FELONIUK, 2015, p. 12). Ora, o texto espanhol (que chegou a viger brevemente no Brasil $^{6}$ ) influiu até mesmo na transformação das Capitanias Hereditárias em Províncias?

A contribuição portuguesa veio da sua Constituição de 1822, ainda como Reino Unido de Portugal, Brasil e Algarves, que contou, na sua elaboração, com a participação de alguns delegados brasileiros, que viriam, posteriormente, a influenciar no projeto da Constituinte de 1823 e na Constituição de 1824. Esta Constituição luso-brasileira teve, por sua vez, seu texto base fortemente influenciado pela

6 "Dom João VI aceitou então plenamente a demanda e elaborou um decreto outorgando a Constituição de Cádiz enquanto não era terminada a elaboração do texto em Portugal. Em 21 de abril de 1821, foi outorgada a norma espanhola no Brasil. [...] O monarca não atendeu ao pedido do ministro e decidiu revogar seu decreto anterior. Ao meio-dia do dia 22 de abril de 1821 a Constituição de Cádiz deixou de viger no Brasil." Em FELONIUK, 2014, p. 33-36.

7 “A origem desse novo modelo é espanhola, origina-se no sistema implantado pela Constituição da Monarquia Espanhola, de 1812, a Constituição de Cádiz. O sistema provincial não foi implantado pela vontade consciente dos criadores da Constituição de 1824 ou mesmo da assembleia dissolvida de 1823. A Revolução Portuguesa, fortemente influenciada pelo liberalismo espanhol, é que adotou com grande fidelidade o modelo da Constituição de Cádiz na implantação do seu projeto político e acabou impondo a organização provincial espanhola no Brasil." Em FELONIUK, 2014, p. 241. 
Constituição de Cádiz e pelas experiências francesas (FELONIUK, 2015, p. 222-224).

Enfim $^{8}$, após a sua elaboração, uma cópia da Constituição foi enviada para cada câmara municipal do Brasil, sendo aprovada por todas ${ }^{9}$, numa tentativa de se abafarem as vozes que falavam contra $o$ ato unilateral do Imperador. ${ }^{10}$ Ocorre que, mesmo com todas estas críticas, é conhecido que Dom Pedro I era um apoiador das ideias liberais ${ }^{11,12}$. Não é intento desta pesquisa adentrar na alçada das atitudes de Dom Pedro I, mas é válido ressaltar que a Constituição outorgada por nosso primeiro monarca foi, ao mesmo tempo, conservadora e liberal:

\begin{abstract}
${ }^{8}$ Não se deve olvidar que parte significativa do projeto da Constituinte brasileira de 1823 (a "Constituição da Mandioca") foi incorporado na Constituição de 1824, eis que o Conselho de Estado utilizou como base o projeto da Constituinte.

9 "A 'idéia' predominante entre os gabinetes conservadores da Europa era que, a haver constituição, fosse esta sob a forma de uma Carta outorgada pelo soberano e não de uma declaração de direitos, equivalente a uma expressão da soberania nacional e das garantias inerentes à atividade do cidadão. Tal era também a preferência de Dom Pedro, que ele não ousou formular em 1822 porque tinha presente a sábia recomendação paterna; que o levou no ano imediato a dissolver a Constituinte; que o fez procurar em $1824 \mathrm{o}$ meio-termo de uma constituição redigida por uma comissão $a d$ hoc e aprovada pelas câmaras municipais [...]" Em LIMA, 1921, p. 293-294.

10 "O efeito produzido no país pela dissolução da Constituinte foi contraditório [...] No norte, sobretudo, a impressão foi detestável. Na Bahia o povo em massa exigiu a reunião da Câmara Municipal e fêz endereçar ao Imperador um protesto contra seu ato, reclamando simultâneamente a liberdade dos deputados presos e deportados. Em Pernambuco, as coisas assumiram logo uma feição mais séria." Em LIMA, 1921, p. 334.

11 "O príncipe herdeiro, cheio de ardor político, andava de coração com os constitucionais [...]" Em LIMA, 1921, p.
\end{abstract} 13.

12 "Não obstante ser militar de carreira, foi sempre San Martin muito mais adepto da doutrina constitucional do que muitos civis, da mesma forma que no Brasil ninguém amou mais românticamente as liberdades políticas do que Dom Pedro, ainda que o temperamento e educação frequentemente o levassem a desprezá-las. A vantagem manifesta do Brasil foi que, adotando a solução monárquica, não procurou nem governante nem regime político alheio às suas tradições: apenas adaptou a monarquia aos novos princípios, tornando-a não só constitucional, como democrática." Em LIMA, 1921, p. 26. conservadora por ser centralizadora e positivar o Poder Moderador; liberal por conceder amplas garantias individuais, algo raro em sua época.

Tal constituição foi a de maior duração da história brasileira, tendo estado vigente por 65 anos. A título de comparação, em 1889, era a segunda constituição há mais tempo em vigência, sendo superada em idade somente pela constituição dos Estados Unidos da América. Esse tempo de duração, bem como a estabilidade do Império Brasileiro em meio ao caos que consumiu o restante da América Latina neste período, contribuiu para a exaltação do regime adotado pela Constituição, vide um dos maiores juristas do Império, o Marquês de São Vicente (1978, p. 28-29):

Certamente, a forma de governo que preferimos é a mais elevada, filosófica e apropriada ás necessidades e porvir do Brasil [...] Por sua condição monárquica, isto é, de um só centro moderador e executivo, único e permanente, não só por sua vida, mas mesmo hereditariamente, como depois veremos, por essa concentração de todas as atribuições que não são legislativas, em que esse centro todavia tem parte, ou judiciárias, sobre que ainda assim tem inspeção, por essa unidade central, esta forma de governo simboliza a unidade e a força nacional, a estabilidade na vida interior do Estado e nas suas relações internacionais. É o princípio homogêneo e harmonioso da ação diretora, que evita os graves inconvenientes dos centros coletivos de execução, cruzados e entorpecidos por ideias diferentes e opostas, debilitados por vontades ou forças desencontradas, ou antes pelo próprio vício de sua instituição. [...] Por seu caráter hereditário desviou o Brasil a nossa forma de governo os males que resultam, e que outros países têm sentido, das monarquias puramente vitalícias ou eletivas, e muito mais dos governos temporários, males que agitam e arruínam as nações. [...] Por sua base constitucional neutralizou os perigos da monarquia pura, da absorção de todo o poder legislativo e judiciário, do poder sem limites, sem contaste, do despotismo, vizinho da tirania.

A Constituição Imperial recebeu, durante toda sua existência, somente uma emenda constitucional, o Ato Adicional de 1834. Este Ato foi amplamente classificado por 
contemporâneos da época ${ }^{13}$ como uma reação, de cunho liberal, frente à hegemonia conservadora das instituições brasileiras, que tinha por objetivo a descentralização do Estado Imperial Brasileiro, inspirados na federação norteamericana ${ }^{14}$, ou seja, visando uma maior autonomia às (então) províncias, conforme expõe Tavares Bastos (1870, p. 22):

É estudando o interesse do nosso país, que perguntamos: Não será tempo de rever as leis e os decretos parasitas quem amputaram a reforma de 1834, renovando a centralização contra a qual se insurgiram as províncias? Será justo que nenhum quilômetro de caminho de ferro se possa construir na mais remota parte do império, sem que o autorize, sem que o embarace, o demore ou o condene o governo da capital? Será razoável que o Pará, há mais de 14 anos, solicite uma ponte para a alfândega; Pernambuco, desde 1835, a construção do seu porto; e o Rio-Grande do Sul, desde a independência, um abrigo na costa?

Seu projeto original previa, inclusive, a supressão do Poder Moderador, do caráter vitalício do Senado e do Conselho de Estado, além de maior autonomia às províncias, reformas que transformariam a monarquia brasileira, literalmente, numa "Monarquia Federativa"15.

Mas nem todos exaltavam com tanto entusiasmo como o de Tavares Bastos o projeto de reforma constitucional. Assim defendeu a redação original da Constituição Imperial Antonio Pereira Rebouças, em discurso na Câmara dos Deputados (1868, p. 6-13), que vale a pena ter transcrito alguns de seus pontos na íntegra ${ }^{16}$ :

\footnotetext{
13 Nesse sentido, ver BASTOS, 1870 e REBOUÇAS, 1868.

14 "Em 1831 uma revolução nacional tentara quebrar o molde antigo que comprimia o Brazil, e imitar francamente os modelos americanos." Em BASTOS, 1870, p. 79.

15 “'O governo do império do Brazil será uma monarquia federativa', dizia a primeira das reformas constitucionais proposta pela câmara dos deputados. Projeto de 14 de outubro de $1831, \S 1^{\circ}$, suprimido pelo senado." Em BASTOS, 1870 p. 15.

${ }^{16}$ Recomenda-se a leitura por completo do discurso, eis que apresenta várias comparações e referências a constitucionalistas da época.
}

'É só constitucional o que diz respeito aos limites e atribuições dos direitos políticos, etc.' Ora, o projeto desta Câmara não trata só e congruentemente da reforma de algum artigo constitucional, mas de toda a Constituição mesma, já mudando a forma de governo proclamado pela nação, jurado e sustentado por ela, já suprimindo um dos poderes políticos essenciais á mesma forma de governo monárquico constitucional representativo, já distribuindo suas atribuições, etc. Por conseguinte, o projeto desta Augusta Câmara está contra a constituição ou fora dela [...] $\mathrm{O}$ art. $1^{\mathrm{o}}$ da Constituição diz expressamente que: 'O Império do Brasil é uma associação política de todos os cidadãos brasileiros, formando uma nação livre e independente.' E o art. $3^{\circ}$ declara que: 'O governo é monárquico hereditário constitucional e representativo.' Ora, o projeto que foi desta Augusta Câmara ao Senado e regressou com as emendas do Senado, diz que: 'O governo do Brasil será uma monarquia federativa'; espécie de associação política, que não nos tem ainda sido definida nem mesmo por seus maiores entusiastas. Logo o projeto diz o contrário do que a nação proclamou e jurou [...] No art. 10 se estabeleceu que os poderes políticos do Estado, reconhecidos pela Constituição do Império são quatro: o Poder Legislativo, o Poder Moderador, o Poder Executivo, o Poder Judicial. [...] No cap. $5^{\circ}$ art. 98 diz que: 'O Poder Moderador é a chave de toda a organização política, e é delegado privativamente ao Imperador, como chefe supremo da nação e seu primeiro representante, para que incessantemente vele sobre a manutenção da independência, equilíbrio e harmonia dos poderes políticos.' Ora, o projeto desta Augusta Câmara determina que ' $A$ constituição (o que expressamente importa a que se faria e não a presente) reconhecerá tão somente três poderes políticos: o Legislativo, o Executivo e o Judicial.' [...] Quando, porém, meus senhores, nós tivéssemos autoridade ampla para decretar, não só que a Constituição fosse reformada, mas que fosse totalmente mudada, cumprida, de acordo com os progressos da perfectibilidade do espírito humano, que não deixássemos estar o governo monárquico constitucional representativo, para adotarmos insensatos uma Monarquia federativa? Cumpriria, a intuito de melhoramento, que suprimíssemos de nossa Lei fundamental um poder neutro, conservador do equilíbrio e harmonia dos demais poderes sociais?

O projeto que foi aprovado ${ }^{17}$ era mais duvidoso no quesito liberal. Percebe-se que é um

${ }^{17}$ Sobre o debate acerca do Ato Adicional, recomenda-se também a leitura de FIGUEIRÊDO, 1986. 
produto de concessões realizadas por ambas as correntes políticas dominantes da época, Liberais e Conservadoras (organizadas em partidos políticos somente mais tarde), pois apesar de realmente dar mais poderes às províncias, concedendo-as, por exemplo, autonomia legislativa, e de suprimir o Conselho de Estado ${ }^{18}$, e de, de facto, introduzir uma "experiência republicana" no Império ${ }^{19}$, tal ato centralizou a Regência numa só pessoa, quando anteriormente era nos moldes de um Triunvirato, bem como manteve a existência do Poder Moderador.

Por fim, essa revolução liberal do Ato Adicional de 1834 foi parcialmente revertida pela Lei $\mathrm{n}^{\mathrm{o}} 105$ de 12 de maio de 1840, a chamada Lei de Interpretação do Ato Adicional, que, no entanto, manteve um relativo autogoverno das províncias, sendo mantida uma espécie de "laço federativo" pela nomeação dos presidentes de província pelo Imperador (TORRES, 1964, p. 63). Isso, por si, mostra outra das peculiaridades desta Constituição: sua semi-rigidez, eis que a Lei de Interpretação foi uma lei ordinária, não outra Reforma Constitucional $^{20}$.

Esta característica está positivada no art. 178 da Constituição Imperial, ipsis litteris: “Art. 178. É só Constitucional o que diz respeito aos limites, e atribuições respectivas dos Poderes Políticos, e aos Direitos Políticos, e individuais dos Cidadãos. Tudo, o que não é Constitucional,

\footnotetext{
18 "Art. 32. Fica suprimido o Conselho de Estado, de que trata o Título $5^{\circ}$, Capítulo $7^{\circ}$ da Constituição." Em BRASIL, 1834.

19 “Art. 26. Se o Imperador não tiver Parente algum, que reúna as qualidades exigidas no art. 122 da Constituição, será o Império governado, durante a sua menoridade, por um Regente eletivo e temporário, cujo cargo durará quatro anos, renovando-se para esse fim a eleição de quatro em quatro anos." BRASIL, 1834.

${ }^{20}$ Observe-se que tal Lei de Interpretação obedece em sua tramitação ao rito ordinário, tendo em vista duas disposições constantes da Carta do Império. Assim, por meio de uma lei ordinária, "a Assembléia Geral faz a reforma da reforma, interpreta os principais dispositivos do Ato [...]" Em FIGUEIRÊDO, 1986, p. 316.
}

pode ser alterado sem as formalidades referidas, pelas Legislaturas ordinárias." (BRASIL, 1824).

Ora, da leitura de tal artigo depreende-se a facilidade com que se poderiam realizar mudanças realmente fundamentais no Império. Se levado ao pé da letra, até mesmo a forma de governo "monárquico hereditário, constitucional e representativo" poderia ser modificada por meio de uma simples legislatura ordinária ${ }^{21}$, assim como outras questões sociais, como, por exemplo, o estigma da escravidão (que foi, efetivamente, extinto por legislação ordinária ${ }^{22}$ ).

Enfim, a Constituição do Império Brasileiro foi um documento ímpar por vários motivos: Foi uma das únicas a estabelecer, nas Américas, a monarquia como modelo de governo; foi a Carta Constitucional brasileira que por mais tempo se manteve vigente; era semirígida; e foi uma das únicas do mundo (juntamente com a Constituição portuguesa de 1826) a literalmente estabelecer, além dos três poderes tradicionais (Executivo, Legislativo e Judiciário), um quarto poder, o Poder Moderador, inspirado nos dizeres do suíço naturalizado francês Benjamin Constant. Ao Imperador coube a chefia dos Poderes Moderador e, ao menos nominalmente, do Executivo, conforme o Título $3^{\circ}$ da Constituição Imperial $^{23}$.

21 "Viva a monarquia! Forma de governo que a imensa maioria da Nação abraça e a única que pode fazer sua felicidade e sua grandeza.[...] Sim, viva a monarquia brasileira, tão democrática, tão abnegada, tão patriótica, que seria a primeira a conformar-se com os votos da Nação, e não lhe opor o menor obstáculo, se ela, pelos seus órgãos competentes manifestasse o desejo de mudar de instituições!" Em OURO PRETO, 1891, p. 222.

${ }^{22}$ Lei $\mathrm{n}^{\circ} 3.353$, de 13 de maio de 1888 , popular "Lei Áurea".

23 "TITULO 3": Dos Poderes, e Representação Nacional. Art. 9. A Divisão, e harmonia dos Poderes Politicos é o princípio conservador dos Direitos dos Cidadãos, e o mais seguro meio de fazer effectivas as garantias, que a Constituição offerece. Art. 10. Os Poderes Politicos reconhecidos pela Constituição do Imperio do Brazil são quatro: o Poder Legislativo, o Poder Moderador, o Poder Executivo, e o Poder Judicial. Art. 11. Os Representantes da Nação Brazileira são o Imperador, e a Assembléa Geral. 


\subsection{Os poderes conferidos ao monarca pela Constituição: o Poder Moderador e o poder Executivo}

\section{Conforme exposto, a Constituição Imperial} teve forte influência espanhola, mas também francesa, tanto pelos acontecimentos como por um pensador, Benjamin Constant ${ }^{24}$. Constant dividiu os poderes estatais em cinco: o Poder Real, o Poder Executivo, o Poder Representativo, o Poder Legislativo e o Poder Judiciário. Costa Júnior (2002, p. 32) e Torres (1964, p. 73) dizem que essa divisão foi integralmente adotada pelo códex de 1824, apesar do Monarca extrapolar a função do Poder Real (Régio ou Moderador):

A vontade nacional, de sua dupla origem, dividia-se em cinco poderes principais, exercidos por meio de combinações entre as duas grandes vontades da nação: o Poder Legislativo, o Poder Moderador, o Poder Representativo, o Poder Executivo e o Poder Judiciário. A constituição mencionava somente 4, por estar o 'poder representativo' incluído no Poder Legislativo. De fato, as funções públicas do Império Brasileiro eram: a legislativa, a representativa, a régia (ou moderadora), a executiva e a judiciária. Os órgãos destas funções eram: do Poder Legislativo - o Imperador, o Senado, a Câmara e o Conselho de Estado; do Moderador - o Imperador e o Conselho de Estado; do Representativo - a Câmara e o Senado; do Executivo - o Imperador, os ministros e os Presidentes de Província; do Judiciário - o Imperador e os juízes e tribunais criados por lei, e, em certos casos, o Senado.

Constant pregava a criação de um poder que fosse neutro frente aos outros poderes, conforme Constant (1991, apud LYNCH, 2012, p. 5):

Em todos os governos, é preciso que haja uma autoridade, não ilimitada, mas discricionária. Essas duas coisas foram confundidas; e dessa confusão resultaram muitos males. É preciso que essa

Art. 12. Todos estes Poderes no Imperio do Brazil são delegações da Nação." Em BRASIL, 1824.

${ }^{24}$ Autor de Principes de Politique (Paris, 1815). autoridade discricionária jamais se dirija aos homens, pois os homens devem sempre estar a salvo do arbítrio. Ela deve dirigir-se aos poderes e deve retornar às mãos de quem não possa jamais apoderar-se deles ou deixá-los às suas criaturas. Assim, o poder preservador não pode ser encarregado de nenhuma eleição, para que ele jamais tenha interesses a desbancar. Assim, sua autoridade discricionária será puramente preservadora.

Justificava-se a criação de tal poder, neutro e, em certa maneira, superior aos demais poderes, como uma defesa da liberdade do povo contra qualquer tipo de opressão, proveniente tanto dos demais poderes estatais (e suas digladiações), insurgências militares, ou, até mesmo, de revoltas populares ${ }^{25}$, "não tendo (o monarca) outro interesse que a manutenção da ordem e da liberdade" (TORRES, 1964, p. 88.).

Ou seja, na teoria de Constant, o monarca teria um poder exclusivamente seu, não exercendo funções nos outros poderes, sendo uma figura apolítica que pairava sobre os demais poderes, atuando em crises provenientes dos conflitos entre os demais poderes. E, em ordem para ser uma figura apolítica, o chefe de Estado deveria ser um monarca, conforme Lynch (2007, p. 75-78):

[...] para exprimir a unidade da soberania nacional, ele paradoxalmente não poderia ser eleito pela nação. [...] Descartada a eleição a prazo certo, restavam a hereditariedade e a vitaliciedade como modalidades de mandato para os postulantes ao exercício do Poder Moderador [...] A queda da autocracia bonapartista em 1814 e a restauração dos Bourbons na França, sob uma constituição que comportava o governo representativo, resolveu na prática o problema teórico de que Constante não conseguia se desembaraçar. Ele propôs então estabelecer os contornos doutrinários da monarquia constitucional, declarando a natureza limitada da soberania popular e fazendo do chefe de Estado o responsável pelo controle estrutural da

25 “O exercício do poder moderador é quem evita nos perigos públicos o terrível dilema da ditadura ou da revolução; todos os atributos do monarca levam suas previdentes vistas a não querer nem uma nem outra destas fatalidades, que quase sempre se entrelaçam e reagem." Em SÃO VICENTE, 1978, p. 204. 
constitucionalidade. Para dar visibilidade simbólica àquela soberania e ao mesmo tempo moderar a representação eletiva, o monarca deveria pairar inviolável sobre os poderes constituídos.

O Poder Moderador foi positivado no Título $5^{\circ}$ (do Imperador), capítulo I da Constituição Imperial ${ }^{26}$, donde é possível extrair a essência do Poder Moderador e, da própria função da Coroa, no Estado Imperial brasileiro: conforme teorizado por Constant, o Monarca é o chefe privativo do Poder Moderador, agindo depois de ouvido o Conselho de Estado ${ }^{27}$, mas

\footnotetext{
26 “Art. 98. O Poder Moderador é a chave de toda a organisação Politica, e é delegado privativamente ao Imperador, como Chefe Supremo da Nação, e seu Primeiro Representante, para que incessantemente vele sobre a manutenção da Independencia, equilibrio, e harmonia dos mais Poderes Politicos.
}

Art. 99. A Pessoa do Imperador é inviolavel, e Sagrada: Elle não está sujeito a responsabilidade alguma.

Art. 100. Os seus Titulos são "Imperador Constitucional, e Defensor Perpetuo do Brazil" e tem o Tratamento de Magestade Imperial.

Art. 101. O Imperador exerce o Poder Moderador

I. Nomeando os Senadores, na fórma do Art. 43.

II. Convocando a Assembléa Geral extraordinariamente nos intervallos das Sessões, quando assim o pede o bem do Imperio.

III. Sanccionando os Decretos, e Resoluções da Assembléa Geral, para que tenham força de Lei: Art. 62.

IV. Approvando, e suspendendo interinamente as Resoluções dos Conselhos Provinciaes: Arts. 86, e 87.

V. Prorrogando, ou adiando a Assembléa Geral, e dissolvendo a Camara dos Deputados, nos casos, em que o exigir a salvação do Estado; convocando immediatamente outra, que a substitua.

VI. Nomeando, e demittindo livremente os Ministros de Estado.

VII. Suspendendo os Magistrados nos casos do Art. 154.

VIII. Perdoando, e moderando as penas impostas e os Réos condemnados por Sentença.

IX. Concedendo Amnistia em caso urgente, e que assim aconselhem a humanidade, e bem do Estado." Em BRASIL, 1824.

27 “Art. 137. Haverá um Conselho de Estado, composto de Conselheiros vitalícios, nomeados pelo Imperador. [...] Art. 142. Os Conselheiros serão ouvidos em todos os negócios graves, e medidas gerais da pública Administração; principalmente sobre a declaração da Guerra, ajusetes de paz, negociações com as Nações Estrangeiras, assim como em todas as ocasiões, em que o Imperador se proponha a exercer qualquer das atribuições próprias do Poder Moderador, indicadas no Art. 101, á exceção da VI.” Em BRASIL, 1824. não atrelado às decisões de tal conselho; tal poder é a chave (ou melhor traduzindo, o fecho $^{28}$ ) da organização política, saneando os conflitos entre os demais poderes; o Monarca é irresponsável (o que será tratado em tópico próprio). Conforme elencado por Costa Júnior, "A importância do Poder Moderador é manter certa influência, a fim de garantir a alternância de poder, a dissolução da Câmara dos Deputados em caso de crise política e a possibilidade de reformas sucessivas infraconstitucionais (leis ordinárias) [...]" (2002, p. 38).

Ou seja, percebe-se que, apesar de acatar, em parte, as ideias de Constant, a máxima “ $O$ Rei Reina, mas não governa” foi modificada para "O Rei Reina, Governa, e Administra"29, vez que

28 "Mas para Afonso Arinos a tradução realizada pelo conselho de estado não foi tão cuidadosa. $\mathrm{Na}$ opinião do jurista o redator do texto constitucional cometeu um erro ao interpretar a palavra clef, cujo significado adequado ao contexto seria o de "fecho", não o de "chave". O erro geraria graves consequências na estruturação do sistema político brasileiro: a transformação de um poder passivo concebido apenas para coordenar as atividades dos demais em uma força ativa de imposição política, isenta de responsabilidade jurídica; e o debate interminável entre alguns dos maiores publicistas brasileiros acerca do significado correto da norma constitucional." Em GUANDALINI JUNIOR, 2016, p. 17.

29 "O debate acerca da distinção entre governo e administração, que pode parecer acadêmico, mas é de importância indiscutível, já que inúmeros problemas somente serão satisfatoriamente resolvidos se esta distinção se fizer com justeza, não deu, parece, tanta bulha quanto a outra, dentro do assunto deste capítulo algo escolástico, entre 'reinar' e 'governar'. Foi um dos pontos de divergência entre liberais e conservadores. Encheríamos volumes com a história da discussão no Parlamento Brasileiro. A solução do Visconde do Uruguai parecerá especiosa, mas é sensata: de acôrdo com certas constituições, o rei reina, mas não governa; de acordo com outras - entre as quais a nossa - faz uma coisa e outra. Os liberais poderiam retrucar dizendo que a Constituição estava errada e que havia necessidade de uma reforma, que seria a eliminação do Poder Moderador. Mas a existêcia do Poder Moderador não é reconhecidamente tácita de que há uma distinção entre as funções régias e as de governo? [...] Nos regimes em que, contráriamente ao nosso, o rei exerce apenas a chefia nominal do Poder Executivo, dois perigos ameaçam constantemente a vida nacional. $\mathrm{O}$ monarca é uma pessoa dotada de senso de responsabilidade, capacidade de trabalho e interesse pela coisa pública e, neste caso, procura intervir na vida política 
tem um grau de influência, além da reguladora, nos demais poderes, como fica bem exemplificado no Poder Executivo do Império, a saber:

O Poder Executivo foi positivado no Título $5^{\circ}$ (do Imperador), capítulo II da Constituição Imperial ${ }^{30}$. Nesse sentido, sobre a distinção entre o Poder Régio (Moderador) e o Poder Executivo, afirma Benjamin Constant (CONSTANT, 1814, apud GUANDALINI JUNIOR, 2016, p. 33):

Mas consideremos o poder executivo, ou seja, os Ministros, como um poder à parte, que o poder real está destinado a reprimir, pela destituição, como reprime, pela dissolução, as assembleias representativas, a responsabilidade do poder executivo se torna razoável, e a inviolabilidade do poder real é assegurada.

Dirão que o poder executivo emana do Rei? Sem dúvida, mas ainda que emane do Rei, ele não é o Rei, assim como o poder representativo não é o povo, ainda que emane do povo [...]

Nós mostraremos que [...] quando o poder executivo não é distinguido do poder real, isso é uma fonte de confusão na teoria, e de perigo na prática.

Denota-se, de primeiro plano, que o Poder Executivo não é privativo do monarca: ele o executa por meio de seus ministros, os quais ele poderia "nomear e demitir livremente" (art. 101, VI, da Constituição Imperial).

$\mathrm{Da}$ análise dos respectivos artigos que positivam os poderes Moderador e Executivo, observa-se uma contradição, ou melhor, uma nebulosidade na separação dos poderes. Ora, o título concernente ao Executivo postula que " $\mathrm{O}$

deixando de ser o chefe nominal para ser o chefe real do Poder Executivo, situação que provoca choques inevitáveis, ou, então, torna-se uma figura mais ou menos decorativa, anulando-se em ocupações fúteis ou francamente indignas." Em TORRES, 1964, p. 93-94.

30 “Art. 102. O Imperador é o Chefe do Poder Executivo, e o exercita pelos seus Ministros de Estado.

$[\ldots]$

Art. 104. O Imperador não poderá sahir do Imperio do Brazil, sem o consentimento da Assembléa Geral; e se o fizer, se entenderá, que abdicou a Corôa." Em BRASIL, 1824.
Imperador é o chefe do Poder Executivo, e o exercita pelos Ministros de Estado". Porém, é por meio do Poder Moderador que o Imperador nomeia e demite os Ministros.

Diante do que já foi exposto, a positivação de tal atribuição do monarca parece, se não o é, estratégica: o monarca, no uso de sua chefia privativa do Poder Moderador, é inviolável, sagrado e não está sujeito à responsabilidade alguma. Exerce o Executivo por meio de seus ministros, mas constitui os ministros usando a prerrogativa do Poder Moderador. Ou seja, a forma como tais prerrogativas foram positivadas implicam uma deliberada ausência de responsabilidade do monarca sobre quaisquer de seus atos, sendo alguns referendados pelos Ministros (os do Executivo) e outros totalmente independentes (os do Moderador). Essa questão da responsabilidade ministerial marcou $\mathrm{o}$ Segundo Reinado (SOUZA, 1864, p. 12):

Bem ou mal, tivemos a infelicidade de ver gravemente comprometida a causa da verdadeira monarquia, a causa da monarquia real na famosa questão da responsabilidade dos ministros pelos atos do Poder Moderador; questão que, bem longe de ser meramente teórica ou especulativa, como alguns têm pretendido, pareceu-nos pelo contrário de maior e mais incalculável interesse prático.

\subsection{O sistema representativo: a criação do cargo de Presidente do Conselho de Ministros, a irresponsabilidade imperial e a responsabilidade ministerial}

Tendo em vista uma "adaptação" da Constituição Imperial ao sistema Parlamentarista (ou sistema Representativo, nas palavras do Decreto) e também uma maior aproximação com o sistema teorizado por Benjamin Constant ${ }^{31}$, em

\footnotetext{
31 "Um monarca hereditário pode e deve ser irresponsável; é um ser à parte, colocado acima do edifício. A sua atribuição, que lhe é particular e que é permanente, não sómente nele, mas em toda a sua raça, de seus antepassados a seus descendentes, separa-o de todos os indivíduos de seu império." Em CONSTANT, 1861, apud TORRES, 1964, p. 87.
} 
20 de julho de 1847 foi elaborado o Decreto $n^{\circ}$ 523 , criando, de facto, se não de jure, o cargo de primeiro ministro (Presidente do Conselho de Ministros).

Tomando em consideração a conveniência de dar ao Ministério uma organização mais adaptada ás condições do Sistema Representativo: Hei por bem criar um Presidente do Conselho dos Ministros; cumprindo ao dito Conselho organizar seu regulamento, que será submetido à Minha Imperial Aprovação. (BRASIL, 1847).

A responsabilidade ministerial foi positivada no Título $5^{\circ}$ (do Imperador), capítulo VI da Constituição Imperial ${ }^{32}$, assim como no artigo 143 da referida Carta, que previu também a responsabilidade dos Conselheiros de Estado: “Art. 143. São responsáveis os Conselheiros de Estado pelos conselhos, que derem, opostos ás Leis, e ao interesse do Estado, manifestamente dolosos." (BRASIL, 1824).

Foi demonstrado anteriormente que o monarca brasileiro, por força da Constituição, não poderia ser responsabilizado por seus atos, fossem eles no exercício dos Poderes Moderador ou Executivo, com a ressalva de que os do Executivo deveriam ser referendados pelos Ministros.

\footnotetext{
32 “Art. 131. Haverá differentes Secretarias de Estado. A Lei designará os negocios pertencentes a cada uma, e seu numero; as reunirá, ou separará, como mais convier.

Art. 132. Os Ministros de Estado referendarão, ou assinarão todos os Actos do Poder Executivo, sem o que não poderão ter execução.

Art. 133. Os Ministros de Estado serão responsaveis

I. Por traição.

II. Por peita, suborno, ou concussão.

III. Por abuso do Poder.

IV. Pela falta de observancia da Lei.

V. Pelo que obrarem contra a Liberdade, segurança, ou propriedade dos Cidadãos.

VI. Por qualquer dissipação dos bens publicos.

Art. 134. Uma Lei particular especificará a natureza destes delictos, e a maneira de proceder contra elles.

Art. 135. Não salva aos Ministros da responsabilidade a ordem do Imperador vocal, ou por escripto.

Art. 136. Os Estrangeiros, posto que naturalisados, não podem ser Ministros de Estado." Em BRASIL, 1824. (grifou-se)
}

Tendo isso em vista, para tornar uniformes as opiniões e atos realizados pelos ministros do Poder Executivo, bem como impedir a interferência excessiva do monarca nos atos do Executivo $^{33}$, foi criado o cargo de Presidente do Conselho de Ministros, em 1847.

Tal criação é importantíssima, eis que impede que o monarca, ao escolher ministros para o gabinete, forme um ministério destoante entre si, com ministros de uma ou outra filiação política conforme a dicotomia da época (ministros de um mesmo gabinete integrantes, um, do Partido Conservador, e outro, do Partido Liberal).

Mais que isso, demonstra o nascimento do parlamentarismo brasileiro ${ }^{34}$, eis que se transfere (ao menos de jure, se não de facto) a responsabilidade de nomeação dos ministros ao Presidente do Conselho, e não mais ao monarca, o que torna o gabinete mais politizado (eis que segue a posição dominante no parlamento), e assim, mais homogêneo ${ }^{35}$. Claro, o Presidente

33 "Os negócios, cuja resolução dependa de assinatura do imperador é que, ordinariamente, lhe são apresentados, quando, aliás, outros muitíssimos mais importantes são resolvidos por ato simplesmente do ministro da respectiva repartição, e por abuso não são assim previamente examinados pelo imperador. Este deve sempre dizer, com a maior franqueza, o que pensa aos ministros sobre os negócios apresentados, e, se divergir do parecer do Ministério, nunca deve fazê-lo de modo que suspeitem que ele quer impor a sua opinião, e não insista mesmo muito senão quando entender que pode provar ser ela a que se baseia na lei ou na justiça. Só quando nesse caso a ilegalidade ou a injustiça for flagrante, o que raras vezes sucederá, é que não deve o imperador recuar ante a necessidade da demissão de qualquer ministro ou do Ministério, procurando o novo no mesmo partido político, se este não se mostrar solidário nessa ilegalidade ou injustiça. A dissolução, isto é, o apelo à Nação, caso dos mais graves, tornar-se-á, então, necessário, e, como as eleições bem longe estão do que desejamos que elas sejam, ainda com mais circunspeção se deve proceder em tais casos." Em PEDRO II, 1871.

34 "O que caracterizava o regime parlamentar era a responsabilidade ministerial pelos atos praticados por uma Coroa irresponsável” em FRANCO, 1957, p. 246.

35 "O presidente do conselho de ministros, que, para haver a indispensável solidariedade entre os ministros, deve ser quem os indique ao imperador, que, aliás, tem a liberdade 
seria nomeado pelo Imperador, no exercício das atribuições do Poder Moderador, mas obrigatoriamente (na teoria) deveria tal Presidente ser o líder da (ou apontado pela) maioria no Parlamento.

Ocorre que, de jure, o Presidente do Conselho de Ministros deveria ser o líder da maioria do Parlamento. De facto, a história foi diferente, criando o chamado "Parlamentarismo às avessas".

\section{O PARLAMENTARISMO ÀS AVESSAS E O GRAU DE UTILIZAÇÃO DOS PODERES CONFERIDOS AO MONARCA DURANTE O SEGUNDO REINADO}

\section{Para se falar sobre o poder exercido de} facto pelo chefe de Estado e de Governo brasileiro durante o Segundo Reinado, é necessário, prefacialmente, explanar $\mathrm{o}$ funcionamento do sistema parlamentar do Império, para então adentrar no poder exercido pelo monarca, eis que, dependendo da época, o monarca utilizava mais, (ou menos), de suas prerrogativas, influenciando de diferentes maneiras o jogo político brasileiro.

O parlamentarismo se estabeleceu no Império mais pela força do costume, se desenvolvendo com o passar dos anos, conforme ia amadurecendo não só o próprio Estado brasileiro, mas também as discussões políticas e a própria pessoa do monarca. Conforme Franco (1957, p. 243):

\begin{abstract}
Pela constituição, o Governo brasileiro seria monárquico-hereditário, constitucional e representativo. Não era corrente no tempo a expressão governo parlamentar, a qual só se vulgarizou depois da ascensão de Luís Felipe na França. [...] Mas o certo é que, apesar da omissão e mesmo das disposições contrárias da Constituição, o parlamentarismo foi, aos poucos, se
\end{abstract}

de não nomeá-los, a qual não é, contudo, a isenção das regras, que aponta o estudo de nosso sistema de governo [...]" em PEDRO II, 1871. estabelecendo no Brasil, embora nunca houvesse chegado a ser uma prática literalmente estabelecida nem politicamente perfeita. De resto, também na Europa, em princípios do século passado, o sistema parlamentar foi um processo lento de adaptação e não se encontra expressamente estabelecido em nenhum texto constitucional, nem mesmo na Constituição francesa de 1830.

No mesmo sentido, tem-se o que foi dito por Paulino Jacques (1978, p. 5-6):

O parlamentarismo brasileiro existiu de fato, praeter legibus constitutionalis, ao tempo do Império, uma vez que a Constituição não o havia estabelecido, mas adotava algumas práticas parlamentaristas, como a Chefia do Estado distinta da Chefia do Governo, a dissolução da Câmara eletiva, a responsabilidade política ministerial e a presença dos Ministros de Estado no plenário da Assembleia Geral (Câmara ou Senado). Constituiuse, assim, consuetudinariamente, através da observância longa, regular e constante das práticas do sistema, quais a Fala do Trono e a resposta a ela, a apresentação á Câmara dos Deputados do Gabinete Ministerial (para explicar a sua organização e oferecer o programa de Governo), o comparecimento dos Ministros de Estado a qualquer das Câmaras, a fim de pleitear medidas ou responder a interpelações, a apresentação, por deputado, de moções de confiança em favor do Gabinete Ministerial, ou mesmo de desconfiança contra ele, o adiamento, ou prorrogação da Assembleia Geral, e a dissolução da Câmara dos Deputados. Com isso, o sistema logrou assegurar, durante mais de meio século, grandeza cívica, política e militar à Nação brasileira.

Num sistema parlamentarista convencional, são realizadas as eleições para o Parlamento, sendo o Primeiro Ministro proveniente do partido que eleger a maioria da(s) casa(s), normalmente sendo o presidente de tal partido indicado por seu partido/coalizão e nomeado formalmente pelo Chefe de Estado.

Benjamin Constant, fundamento teórico da Constituição Imperial, apontava que sem eleições realizadas correta e honestamente o sistema, por ele criado, não funcionaria perfeitamente. Ocorre que essa era a exata situação em que o Império do Brasil se encontrava: 
Embora Benjamin Constant tivesse sido claro ao frisar que, sem eleições honestas, o sistema representativo não passava de uma ficção - e com ele, todo o arcabouço do Estado liberal por ele delineado, as fraudes foram uma característica de todo o processo político desde pelo menos 1840 e eram promovidas pelos partidos que estivessem no poder para assegurar seu predomínio quase que incontrastável, o que ficava patente nas denominadas "câmaras unânimes", i.e., eleições legislativas onde a oposição mal conseguia cinco cadeiras em cem. Isto importa afirmar que a alternância dos partidos no poder - representantes, por excelência, dos interesses particulares na esfera pública - não seria possível pelo voto nacional, mas somente se houvesse a intervenção de um poder supraoligárquico que pusesse deliberadamente um fim ao domínio de um desses partidos e chamasse o outro ao poder. Por outro lado, os partidos, constituindo verdadeiras frentes políticas fracionadas entre diversos caciques, impunha que o monarca escolhesse algum deles. Isso significa que não somente o poder moderador decidia juntamente com o Conselho de Estado quando era hora de pôr fim a uma "situação" partidária, como ele deveria escolher qual o chefe que deveria ser convocado. Ainda que houvesse praxes nesse processo, envolvendo consultas ao próprio primeiro-ministro demissionário, sempre ficava reservada ao monarca a possibilidade de guiar o processo conforme entendesse mais adequada. (LYNCH, 2012, p. 12)

O Chefe de Estado e de Governo da época reconhecia tal situação, onde as eleições do Império não representavam a real vontade da nação ${ }^{36}$, mas sim os interesses políticos:

36 "O sistema político do Brasil funda-se na opinião
nacional, que, muitas vezes, não é manifestada pela
opinião que se apregoa como pública. Cumpre ao
imperador estudar constantemente aquela para obedecer-
lhe. Difícil,o estudo, com efeito, por causa do modo por
que se fazem as eleições; mas, enquanto estas não lhe
indicam seu procedimento político, já conseguirá muito, se
puder atender com firmeza ao que exponho; sobre as
principais questões, mormente no ponto de vista prático.
Para ajuizar bem delas, segundo os casos ocorrentes, é
indispensável que o imperador, mantendo-se livre de
prevenções partidárias, e portanto não considerando
também como excessos as aspirações naturais e justas dos
partidos, procure ouvir, mas com discreta reserva das
opiniões próprias, às pessoas honestas e mais inteligentes
de todos os partigos; informar-se cabalmente de tudo o que
se disser na imprensa de todo o Brasil, e nas Câmaras
Legislativas da Assembléia-Geral e Provinciais. Não é
Meu grande empenho é a liberdade de eleições. Para isso tenho sempre lembrado a boa escolha de presidentes. Foram até consultados Conselheiros de Estado, que não quiseram aceitar esse encargo. Creio que o Ministério quer a leal execução da nova lei de eleições, mas é indispensável que as autoridades não contradigam esse desejo por seu procedimento mais ou menos desleal. Toda a vigilância e diligência do governo é pouca. Não sei qual será o resultado das eleições; mas, se ele permitir que o poder volte aos liberais, estimá-lo-ei. O que eu almejo é que os Ministérios se sucedam pela opinião da maioria da Câmara. Embora a da que vai ser eleita não seja liberal, se a oposição for tal que embarace a marcha de um Ministério conservador, eu chamaria os liberais para o governo, e sem condições. [...]Se as eleições se fizessem como todos devemos desejar, talvez aconselhasse a

escolha quase constante do mais votado na lista dos propostos para senadores; porém nas circunstâncias atuais cumpre escolher o honesto, o moderado, o que tenha mais capacidade intelectual e serviços ao Estado; porque o Senado não é por sua natureza um corpo onde devam fazer-se sentir as influências partidárias, como na Câmara dos Deputados. Tem de moderar a esta, e de sentenciar em casos de maior importância. Os ministérios vão começando a querer, por interesses partidários, colocar o imperador entre as necessidades de escolher os senadores contra o juízo desse e da demissão daqueles, e é preciso combater essa tendência, por meio da persuasão de escolhas bem fundadas, entre as propostas nas listas, e do que compita ao imperador e aos ministros em tal caso. Tudo depende da consciência e inteligência do imperador e dos ministros. (PEDRO II, 1871)

Essa situação de eleições fraudulentas serviu como justificativa para o monarca, no exercício do Poder Moderador, realizar a alternância dos partidos no poder, já que ela não se realizaria por si só. Tal arranjo foi denominado de "Pacto do Poder Moderador" (COSTA JÚNIOR, 2002, p. 91).

Daí vem nome "Parlamentarismo às Avessas": Se num sistema parlamentarista normal, o primeiro-ministro é, originariamente, o líder da maioria do parlamento, no Império, para se realizar a alternância de poderes, ocorria o contrário:

prudente convocar qualquer outro meio de informação, e cumpre aceitá-lo cautelosamente.” Em PEDRO II, 1871. 
Existia uma maioria do partido " $\mathrm{x}$ " no poder, com o primeiro-ministro sendo do partido " $\mathrm{x}$ ". O Imperador, juntamente com o Conselho de Estado e, na maioria dos casos, com o próprio Presidente do Conselho de Ministros (do partido “x”) decidiam pela alternância de poder ${ }^{37}$. Então nomeava-se um novo Presidente do Conselho de Ministros, desta vez do partido "y". Este presidente nomeava um novo gabinete, tornandose, então, o Presidente do Conselho de Ministros o líder da minoria do congresso (Processo semelhante era realizado quando havia a troca de gabinete dentro do governo de um mesmo partido, só que, na grande maioria das vezes, sem a dissolução da Câmara).

Em seguida, dissolvia-se o parlamento e convocavam-se novas eleições, onde surgiria uma maioria do partido "y". Ou seja, o Executivo fazia a maioria do Parlamento, e não a maioria do Parlamento fazia o Executivo. Se houvesse concórdia no parlamento, a situação continuava essa. Se o embaraço fosse tal que impedisse a boa execução do governo, realizavase novamente tal procedimento. $\mathrm{O}$ inciso $\mathrm{V}$, do artigo 101 da Constituição Imperial, rezava que a dissolução da Câmara dos Deputados deveria ser feita somente em casos que "exigissem a salvação do Estado".

Nesse sentido, importante ressaltar que tal situação era alternada, o que impedia uma ditadura do partido momentaneamente no poder.

\footnotetext{
37 “A Câmara eleita durante o governo do duque de Caxias encerrou sua segunda sessão legislativa em outubro de 1877 e deveria retomar as atividades em maio do ano seguinte. Contudo, Caxias estava velho, doente, e seu governo não tinha o dinamismo daquele de seu antecessor, visconde do Rio Branco. A doença levou-o a pedir demissão a Pedro II, sugerindo-lhe, se não pretendesse chamar os liberais ao poder, manter os demais ministros do seu Gabinete, elevando o barão de Cotegipe para a presidência do Conselho, cargo que este, na realidade, desempenhava informalmente quando o duque se ausentava por motivos de saúde. Os conservadores governavam havia dez anos e Pedro II, diante das demandas de reforma política, retomou o rodízio partidário no poder, nele colocando os liberais [...]" Em DORATIOTO, 2008, p. 219.
}

Pretendia-se manter tal "Pacto do Poder Moderador" até que a população conseguisse expressar sua real vontade por meio das eleições, o que só aconteceria quando o povo fosse suficientemente instruído e as instituições eleitorais fossem robustas o suficiente para que as eleições fossem honestamente realizadas. $\mathrm{Ou}$ seja, a priori, se acatarmos como pressuposto tal ausência de representatividade da população na Câmara por conta das eleições fraudulentas, pode-se enquadrar o rodízio realizado pelo Poder Moderador como essencial para a representatividade nacional e, por conseguinte, a salvação do Estado.

Portanto, com o passar dos anos, conforme o Estado, o monarca e a própria classe política Imperial amadureceram, houve uma diminuição gradual da interferência da Coroa nos assuntos do Executivo, pelo que se faz necessária uma análise dos poderes utilizados de facto pelo Chefe de Estado e de Governo durante certos períodos, analisando o Segundo Reinado como um todo, conforme atesta Costa Júnior:

\footnotetext{
No caso da relação de poder entre chefe de Estado e chefe de governo, no Segundo Reinado, existem três interpretações jurídicas formais sobre a referenda aos atos do chefe de Estado como Poder Moderador (no Conselho de Estado) e no Poder Executivo (no Conselho de Ministros) [...] Não há uma só interpretação de jure, já que o chefe de Estado preside as reuniões do Conselho de Ministros (na presença do chefe de governo) e não há regulamentação da relação de poder entre o chefe de Estado e o chefe de governo (presidente do Conselho de Ministros). Mas, pode ser utilizada a interpretação de facto para uma análise política e empírica, a fim de estabelecer a relação de poder real existente entre o chefe de Estado e o chefe de governo. (COSTA JÚNIOR, 2002, p. 45)
}

Assim, passa-se a uma análise fática dos períodos do Segundo Reinado.

Nos primeiros anos de seu reinado (18401847), o Conselho de Estado exerce uma tutela sobre o imperador (COSTA JÚNIOR, 2002, p. 94), sendo seu governo "o da salvação nacional" (CARVALHO, 2007, p. 37-43): 
Quando os regressistas subiram ao poder em 1837, foi a vez de os liberais hastearem a bandeira maiorista. Em 1839, o deputado Montezuma apresentou proposta de antecipação da maioridade de d. Pedro. Nascido em 1825, este só atingira a maioridade constitucional aos dezoito anos, isto é, em dezembro de 43. A mudança de mãos da causa maiorista, dos conservadores para os liberais, era indicação de que os grupos políticos, ainda mal organizados em partidos, não tinham encontrado um mecanismo institucional de convivência. Com receio de que o adversário se perpetuasse no poder, decidiram recorrer ao trunfo do poder monárquico, mesmo que fosse necessário colocá-lo nas mãos de um rapazinho. A juventude e a inexperiência do imperador podiam até ser uma vantagem. Sem experiência, ele poderia ser manipulado por quem o levasse ao poder. [...] Do governo do jovem imperador esperava-se muito. A elite política esperava que a figura suprapartidária de d. Pedro II reduzisse os conflitos que a dividiam. Esperava, ainda, que a legitimidade centenária da monarquia congregasse a população do país. Em várias revoltas populares da Regência, ficara evidente essa legitimidade. Em 1832, a guerra dos Cabanos em Pernambuco e Alagoas reivindicara a volta de d. Pedro I. Em 1835, a Cabanagem, no Pará, tinha separado a província, mas os rebeldes gritavam vivas a Pedro II. Em 1837, a Sabinada, na Bahia, separara a província até que o monarca fosse declarado maior de idade. Na Balaiada, revolta popular maranhense, também se davam vivas ao imperador menor. As duas coisas, redução do conflito intra-elite e adesão popular, eram condição para a manutenção da ordem social e política e da integridade nacional.

O gabinete, no início, foi chefiado por Aureliano Coutinho, da chamada "facção áulica" (SCANTIMBURGO, 1999, p. 197). Ocorreram nessa época alguns fatos de notoriedade com relação ao poder do Chefe de Estado e de Governo:

Dom Pedro II, pela primeira vez, enfrentou um de seus ministros (o ora Marquês do Paraná), não acatando um pedido do Marquês de demissão de um subalterno, tendo como consequência a demissão do dito Marquês do Gabinete (aplicação do inciso VI do artigo 101 da Constituição Imperial);

O monarca anistiou, em 1844, os integrantes da Revolta Liberal de 1842, e os chamou novamente ao poder (este é o momento da feitura do "Pacto do Poder Moderador") (aplicação do inciso IX do artigo 101 da Constituição Imperial);

A partir da criação do cargo de Presidente do Conselho de Ministros (20 de julho de 1847) até 31 de maio de 1848, o Império teve 03 (três) gabinetes Liberais.

Em 1848, com o pedido de demissão do Gabinete Liberal, chamou novamente os conservadores ao poder. A partir dessa data "[ ... d. Pedro já controlava as rédeas do poder [...] Tinha quase 23 anos, e se livrara também da influência do mordomo Paulo Barbosa [...], e de Aureliano, afastado do paço" (CARVALHO, 2007, p. 47).

Os conservadores ficaram no poder de 1848 até 1862, com 09 (nove) gabinetes. É uma boa demonstração da participação do Presidente do Conselho e dos demais ministros na formação de um novo gabinete dentro do governo de um mesmo partido político, com a indicação de seu sucessor.

Entre 1848-1871, dá-se a consolidação do Estado Imperial, com uma forte presença do Chefe de Estado. O Imperador conduz as questões externas (dentre elas, a questão do Prata; guerra contra Manuel Oribe $[1851]^{38} \mathrm{e}$ Juan Manuel de Rosas $^{39}$ [1852]; Guerra contra

38 “Em virtude da autorização expressa do governo da república do Uruguai, e porque a existência do general Oribe á testa de um exército no território oriental, além de ameaçar a sua independência, é incompatível com a segurança das fronteiras da província de S. Pedro do Rio Grande do Sul, e mesmo com a tranquilidade desta parte do Imperio, ordenei que o nosso exercito operasse ativamente para expeli-lo daquele território. Espero que a execução dessa resolução contribuiráeficazmente para a solução das questões que se têm agitado no Rio da Prata, e para a terminação da prolongada crise em que se tem achado [...]" Em BRASIL, 1889, p. 454-455.

39 "Para a expulsão do general Oribe do território da República Oriental, e manter sua independência, contrai uma aliança com o seu governo e os Estados de Entre-Rios e Corrientes, tendo estes retirado os poderes que haviam conferido a D. João Manoel de Rosas para os representar no exterior [...] Tendo o governador de Buenos Aires formalmente declarado a intenção de fazer a guerra ao 
Aguirre [1864-65]; Guerra da Tríplice Aliança [1864-1870]) e as internas (dentre elas, questão Christie $^{40}$, construção de estradas de ferro, navegação do Amazonas, Lei de Terras, Código Comercial, projeto da Lei do Ventre Livre [1871] (COSTA JÚNIOR, 2002, p. 108-109). Assim atesta um trecho da Fala do Trono na abertura parlamentar de 03 de maio de 1847 :

Cada dia se torna mais imperiosa a necessidade de providenciar sobre a reforma judiciaria, a colonização, o comércio, o recrutamento, e a organização da guarda nacional. Chamo, pois, a vossa atenção sobre cada um destes importantes objetos, que instantemente reclamam o vosso zelo e solicitude. (BRASIL, 1889, p. 414).

O monarca conduzia as questões do gabinete, realizando medidas para combater a corrupção nos sufrágios, mas dependia das deliberações do parlamento, conforme a Fala do Trono da abertura parlamentar de 03 de maio de 1848 e o Voto de Graças apresentado pela câmara em 15 de maio do mesmo ano, respectivamente:

Ser-vos-há apresentada uma proposta relativa à lei de 3 de Dezembro de 1841, e uma outra, que tem por objeto declarar a incompatibilidade da eleição de alguns funcionários públicos nos lugares em que exercerem jurisdição ou autoridade.[...] As propostas relativas à lei de 3 de Dezembro de 1841 , e a incompatibilidade da eleição de alguns funcionários públicos nos lugares em que exercem a

Brasil, contrai com a República Oriental, e com os Estados de Entre-Rios e Corrientes uma nova aliança, em virtude da qual lhes prestei auxílios [...] A vitória coroou esplêndidamente as armas do exército aliado, e o poder de D. João Manoel de Rosas terminou na batalha de MonteCaseros.” Em BRASIL, 1889, p. 464.

40 "Desde 1861, Christie vinha atazanando o governo brasileiro. [...] Imperador e ministério decidiram que nenhum navio de guerra brasileiro, se atacado, arriaria a bandeira, indo de preferência ao fundo. [...] O Imperador desceu de São Cristóvão para o paço da cidade a fim de encorajar a resistência [...] Nesse meio tempo, Mauá, que tinha negócios com os ingleses, e a quem, portanto, não interessava o conflito, tomara por conta própria a iniciativa de propor mediação, no que fora apoiado pelo Marquês de Abrantes, ministro dos Estrangeiros. Pedro II irritou-se com Mauá e desautorizou o ministro." Em CARVALHO, 2007, p. $103-104$. jurisdição e autoridade, serão pela câmara dos deputados atenta e acuradamente consideradas. A justiça senhor, é a primeira necessidade social; a liberdade do voto a principal condição da realidade do sistema representativo. Tal necessidade será satisfeita, tal condição preenchida pelo governo de Vossa Majestade Imperial, se porventura nas propostas anunciadas consignou os melhores meios de garantir a segurança pública, e a liberdade individual, de purificar o exercício do direito eleitoral dos abusos, que ainda infelizmente o perturbam. (BRASIL, 1889, p. 430-433).

Em 1853, Dom Pedro II chamou o Marquês do Paraná, sua primeira desavença política, para formar um gabinete. Aí se deu outro exemplo da condução do Imperador: entregou ao gabinete instruções contendo ideias para o governo perseguir (Introdução da eleição direta, execução da Lei de Terras, colonização, repressão ao tráfico de escravos, construção das estradas de ferro e afastamento dos militares da política) (CARVALHO, 2007, p. 55-56) e ideias acerca do funcionamento do gabinete e sobre como deveriam ser as relações entre o Chefe de Estado e os ministros.

Sobre o funcionamento do gabinete e a relação Chefe de Estado - Ministros, diz Carvalho (2007, p. 56):

A primeira regra dizia que o ministro que jogasse a responsabilidade de sua ação sobre o imperador seria demitido. [...] Outra regra, essa cumprida à risca, foi que as decisões seriam todas tomadas em despacho coletivo do ministério, ou do ministro individualmente com o imperador. Uma terceira diretriz tinha a ver com a não-interferência do governo nas eleições. Para o monarca, o segredo do bom funcionamento do sistema parlamentar de governo estava na realização de eleições confiáveis. Se os ministros manipulassem as eleições, a opinião nacional não se manifestava no Parlamento e o Poder Moderador era obrigado a promover, por conta própria, a rotação dos partidos no governo. [...] Nos papéis do imperador, há um documento em que ele explicita sua posição. A chefia, segundo ele, verifica-se apenas na livre escolha do ministério. Quanto ao resto, reduzia-se a uma supervisão dos ministros, a qual não podia retirarlhes a liberdade de se opor e, eventualmente, pedir demissão. [...] Delegou cada vez mais poder aos 
presidentes, inclusive, em suas próprias palavras, para se acobertar de críticas. No despacho coletivo, chamado de "sabatina", ouvia todos os ministros e fazia anotações a lápis em tiras de papel. Os sete ministros falavam sobre todos os assuntos. D. Pedro discutia, às vezes convencia, às vezes era derrotado.

O mesmo autor ainda complementa, transcrevendo as palavras de Dom Pedro II (CARVALHO, 2007, p. 78):

Procuro cumprir meus deveres de monarca constitucional, e regulo meu procedimento pelos princípios seguintes: os atos do poder moderador não admitem responsabilidade legal; mas, carecendo às vezes de defesa, os ministros que entenderem não poder fazê-lo têm o direito de retirar-se. Estes atos não tem referenda obrigada.

Sobre os atos do poder executivo tem o imperador, como chefe desse poder, inteira inspeção, podendo manifestar sempre a sua opinião com toda a liberdade de exigir dos ministros. Deve ter todo o escrúpulo em insistir em sua opinião para evitar os males da subserviência e desgostos da parte dos ministros. Cumpre ao monarca ser franco para com os ministros; mas fora das ocasiões em que se resolvam os negócios, deve ser o mais reservado possível, ouvindo contudo a todos, e procurando esclarecer por todos os modos convenientes o seu juízo. A respeito do conceito, que forme o monarca dos indivíduos, todo o escrúpulo é pouco, e deve lembrar-se sempre de que os ministros desculpamse as mais vezes com a opinião dele, ou que lhe imputam, quando se acham empenhados interesses individuais. Não sou de nenhum dos partidos para que todos apoiem nossas instituições; apenas os modero, como permitem as circunstâncias, julgando-os até indispensáveis para o regular andamento do sistema constitucional, quando, como verdadeiros partidos e não facções, respeitam o que é justo.

De 1850 a 1862, não há dissolução do parlamento, predominando os Conservadores. A partir de 1855 o Imperador passa a comutar sistematicamente a pena de morte (COSTA JÚNIOR, 2002, p. 109-112).

Em 24 de maio de 1862, forma-se um gabinete Liberal (da Liga Progressista), com a presidência de Zacharias de Góes e Vasconcellos $^{41}$, que foi montado para fazer aprovar no Parlamento a demissão de alguns

${ }^{41}$ Grande constitucionalista do tempo do Império. magistrados prevaricadores, demissões estas requeridas por Dom Pedro II. Tal gabinete cai, sendo formado outro pelo Marquês de Olinda, mas retorna em janeiro de 1864, somente para cair novamente (formando-se outro gabinete Liberal) e retornar em 1866.

$\mathrm{Na}$ senda da Guerra da Tríplice Aliança (1864-1870), válido citar o poder de persuasão utilizado por Dom Pedro II. O monarca, obviamente ansioso pelo sucesso bélico brasileiro, queria aumentar os efetivos nacionais na contenda, bem como visitar o teatro de guerra. O parlamento não aprovou tal ato e o gabinete ministerial estava dividido, tendo o monarca que, não podendo legislar por si só, ameaçar abdicar e ir ao teatro de guerra como "o primeiro Voluntário da Pátria" para que o Parlamento e o gabinete acatassem sua vontade (CARVALHO, 2007, p. 110).

Em julho de 1868 deu-se a "mais grave crise política do Segundo Reinado", advinda de desentendimentos entre o gabinete de Zacharias e o comandante-em-chefe das forças brasileiras na Guerra, o Duque de Caxias (CARVALHO, 2007, p. 117).

Carvalho (2007, p. 59) atesta que "Foi a total confiança no general que levou o monarca a praticamente forçar o gabinete liberal de 1866 a nomeá-lo para o comando das tropas brasileiras no Paraguai". Para aceitar o cargo, Caxias havia exigido a total confiança do gabinete. Ocorre que em 1868, Caxias começou a ser culpado por alguns jornais da capital (em parte subsidiados pelo Executivo) sobre a lentidão da guerra, tendo ainda reclamado que o Presidente do Conselho de Ministros teria passado por cima de sua autoridade.

Ambos, comandante e presidente, pediram demissão. Conseguiu-se adiar a crise, com uma trégua entre ambos, acertada pelo monarca, mas, em referida data, o presidente e todo o ministério demitiram-se sem indicar ao monarca um sucessor (o que contrariava a ordem estabelecida 
pelo Pacto do Poder Moderador), deixando o Poder Moderador sozinho na formação de um novo ministério. Primando pelo bom andamento da guerra, o monarca o fez chamando os conservadores novamente ao poder, os quais estavam apeados do poder desde 1862 e tinham grande entrosamento com Caxias. "Embora constitucional, a decisão provocou enorme celeuma. Os liberais acusaram o imperador de dar um golpe, e o Poder Moderador sofreu seu maior desgaste em todo o reinado." 42 (CARVALHO, 2007, p. 118).

42 "Detratores se insurgiram contra o Conselho de Estado, como detratores se assanharam contra D. Pedro II, um dos maiores estadistas do século XIX, no entanto, fertilíssimo em personalidades políticas de exceção. Arguido de abusar do poder pessoal, amparado na competência do Poder Moderador, era, também, apodado de Pedro banana, isto é, irresoluto. Oliveira Viana forma entre os críticos do Poder Moderador. Confundi-o com uma hipertrofia, o poder pessoal, citando para confirmá-lo, o surrado episódio da queda do gabinete Zacarias, em 1868. Mas não se sustenta a invectiva, esclarecida não só no calor dos fatos, como, no Parlamento, pelo duque de Caxias, em memóravel discurso. D Pedro II não havia praticado e não praticou ditadura do Poder Moderador, acusação na qual incidiu até mesmo Max Fleiuss. Basta a consulta às Atas do Conselho para se ficar esclarecido. [...] é preciso acentuar-se que o imperador atuou como presidente de um governo colegiado [...] Daí ter obedecido, desde a restauração constitucional do Conselho de Estado, ao princípio altamente salutar do governo em colégio de membros de eminente qualificação. Davam as prerrogativas do Poder Moderador a D. Pedro II o direito de governar isoladamente, sobranceiro ao Conselho de Estado, ao Conselho de Ministros, mas o imperador não as usou. Acusá-lo, portanto, de fazer do poder pessoal a nota dominante de sua ação, como chefe de Estado, é mais do que aleivosia, é injusta deformação histórica. D. Pedro II timbrou em governar colegiadamente, como está patente nas Atas do Conselho de Estado. [...] Quando um novo chefe de gabinete, apresentando-se ao parlamento, afirmava, como era de costume, que em tal dia e em tais circunstâncias fora chamado por Sua Majestade para formar o ministério ali presente, estava, sem dúvida, a dizer a verdade. Era realmente o imperador, quem, fazendo vir a São Cristovão o político em evidência, pessoalmente o convidava para organizar o novo governo. Mas a escolha daquele nome para aquela missão não fora inspiração única e pessoal de D. Pedro II. Era obra do Conselho de Estado. Esse, o hábito de governar de D. Pedro II. O chefe do Poder Moderador não renunciava à sua competência, mas, antes, a exercia, apoiando-a nos conselhos, nos argumentos, nas ponderações dos membros de seu
Importa dizer que foram os liberais, na pessoa de Zacharias e de seu ministério, que causaram a crise, não tendo indicado um ministério sucessor ao monarca. Nas palavras de Scantimburgo (1999, p. 200-201):

[...] não poucos estudiosos invocam o saturadamente famoso episódio do gabinete Zacarias, em 1868, para diminuir a presença de D. Pedro na História [...] da leitura da íntegra da Ata do Conselho de Estado, de 18 de julho de 1868, verifica-se que a alta instituição imperial deliberou, rigorosamente, no sentido do interesse nacional, tendo, mesmo, um dos conselheiros, o visconde de Jequitinhonha, abominado à só referência à ideia de ditadura. O Conselho justificou a chamada dos conservadores, ou, nas palavras de São Vicente: 'Não seria admissível restabelecer esse Ministério (Zacarias); quem viria substituí-lo a não ser um Ministério Conservador? Oliveira Viana, suspeito por atribuir ao imperador o uso e mesmo abuso do poder pessoal, argui de acertada a escolha de Sales Torres Homen para o Senado, em lugar de duas mediocridades. Zacarias sentiu-se, sem motivo para tanto, desautorado, e apresentou demissão. O autor aduz, ainda, que homem da respeitabilidade e do prestígio moral de Zacarias 'não coravam de descer a mesquinhas manobras', onde, pois, o golpe de Estado do imperador? A queda do gabinete foi toda armada pelo presidente do Conselho. [...] Em suma, D. Pedro agiu colegiadamente, não se confirmando, nos vinte anos subsequentes do Império, a insinuação - um disse-se - de Oliveira Viana, que o imperador passou a escolher os senadores, segundo a indicação dos presidentes do Conselho. [...] Vê-se perfeitamente que o Poder Moderador deixara de ser um poder pessoal do monarca, pois seu exercício se fazia na base das consultas do Conselho. Continuava, legalmente, privativo do Imperador; na realidade passara a pertencer a uma instituição.

Os Conservadores voltam ao poder em 1868, e aí ficam até 1877, dividindo-se em 04 (quatro) gabinetes. A guerra do Paraguai finda em 1870. Por interferência direta de Dom Pedro II, edita-se o projeto da Lei do Ventre-Livre, aprovada em 1871, no gabinete de presidência do Visconde do Rio Branco.

próximo colégio de colaboradores, todos e de sua mais alta idoneidade, confiança.” Em SCANTIMBURGO, 1999, p. 195-197. 
Rio Branco era mero ministro no gabinete do Visconde de São Vicente, gabinete este formado justamente para a aprovação de referida lei, porém, por força de uma certa inaptidão política de São Vicente, formou-se novo gabinete, presidido pelo Visconde do Rio Branco, político hábil que “[...] enfrentou a oposição feroz dos próprios aliados do ministério. Na câmara, os debates foram os mais longos e violentos que jamais houve. Toda a seção de 1871 foi tomada pelas discussões." (SCANTIMBURGO, 1999, p. 135). Importa dizer que a interferência do monarca deu-se na edição da lei: a aprovação deveu-se aos estratagemas políticos de Rio Branco e de São Vicente, constitucionalista predileto de Dom Pedro II.

No assunto da abolição da escravatura é que mais se veem os limites do poder do chefe de Estado e de Governo desta época. Ora, é bem conhecido que Dom Pedro II era um ferrenho abolicionista, que considerava que "A escravidão é uma terrível maldição sobre qualquer nação, mas ela deve, e irá, desparecer entre nós." Conforme Carvalho (2007, p. 132-133):

Iniciativas mais enérgicas começaram no final da Guerra de Secessão. Em janeiro de 1864, d. Pedro mandou instruções ao presidente do Conselho, Zacarias de Góis, dizendo-se preocupado com o que se passava nos Estados Unidos e sugerindo que o Brasil iniciasse o processo abolicionista com uma lei de libertação do ventre. [...] Os Agassiz anotaram no diário de viagem: 'Se o seu poder igualasse a sua vontade, a escravidão desaparecia do Império de um só golpe'. A superveniência da Guerra da Tríplice Aliança no fim desse ano adiou a discussão. [...] Solicitou, então, a seu constitucionalista preferido, o senador Pimenta Bueno, na época visconde de São Vicente, que redigisse projetos de lei abolicionistas. São Vicente apresentou-lhe em janeiro de 1866 cinco projetos que se tornaram a base para a futura lei da libertação do ventre escravo. Foram levados ao Conselho de Ministros, cujo presidente, o marquês de Olinda, era visceralmente contra a discussão do tema, e não tomou providências. (grifou-se)

O autor continua, demonstrando a pressão realizada pelo monarca:
O Conselho de Estado foi chamado a opinar. Apenas um conselheiro não julgou a medida inoportuna por causa da guerra. Houve críticas diretas ao imperador pela precipitação da iniciativa. O mesmo Rio Branco que quatro anos depois faria aprovar a Lei do Ventre Livre afirmou: 'Não há entre nós um partido que tomasse a peito a abolição da escravidão. Ninguém supunha essa medida tão próxima. 'Nem os mais afoitos, acrescentou, agitariam a questão em situação de guerra, se não fosse a iniciativa imperial. [...] $\mathrm{O}$ ministério do progressista Zacarias concordou, em 1867, em incluir o tema na Fala do Trono. Houve escândalo. [...] O gabinete de Itaboraí não admitiu incluir o tema na Fala do Trono de 1870. Seguiu-se um jogo de astúcias entre o monarca e o presidente do Conselho. Vendo-se em posição contrária à de d. Pedro, Itaboraí decidiu pedir demissão. Cabia a ele indicar um sucessor. [...] Como corressem boatos de que d. Pedro queria São Vicente, o autor dos projetos abolicionistas, indicou-o. $\mathrm{O}$ imperador aceitou com entusiasmo. (CARVALHO, 2007, p. 133-135) (grifou-se).

Ou seja, denota-se que o Chefe de Estado exerceu uma extrema pressão sobre os gabinetes a fim de fazer valer sua vontade. Mas este foi seu limite: exercer pressão. Não pode, de facto, decretar sua vontade.

Renovaram-se as acusações de que o projeto era de inspiração imperial e não nacional. [...] Voltaram também as acusações de despotismo dirigidas contra o Poder Moderador. A situação era esdrúxula e revelava a ironia da representação política no Império. A se dar crédito às posições dos críticos, inclusive republicanos, o abolicionismo era despotismo, o escravismo era democracia. (CARVALHO, 2007, p. 136)

Ainda em 1871, dá-se o "último ato da hegemonia do chefe de Estado em relação ao gabinete e ao Parlamento" (COSTA JÚNIOR, 2002, p. 116): Dom Pedro II decide viajar para a Europa e anuncia a viagem antes da autorização da Assembleia Geral. Ao viajar, deixa a Princesa Isabel na regência do Estado, o que resulta na preponderância dos atos do Executivo.

Ao retornar da viagem, em 1872, Dom Pedro II diminuiu até mesmo suas pressões sobre os assuntos governamentais. Em suas palavras, 
“Eu deixo andar a máquina. Ela está bem montada, e nela tenho confiança. Somente quando as rodas começam a ranger e ameaçam parar, ponho um pouco de graxa." (GONÇALVES, 1955).

Ainda nesse ano, o Imperador dá aos Presidentes do Conselho o direito de demitir os demais ministros, mantendo a prerrogativa de não aceitar algum nome para compor o gabinete, bem como introduz uma responsabilidade dual entre os chefes de facto e de jure do Governo na nomeação dos presidentes das províncias e dos senadores (COSTA JÚNIOR, 2002, p. 123).

Entre 1872 e 1875 tem-se a "Questão Religiosa", que se "resolve" com a anistia dos Bispos em 1875, já no gabinete presidido por Duque de Caxias. Em 1876, o imperador viaja novamente ao exterior, dando início à Segunda Regência da Princesa Isabel, que acaba com a volta do Imperador em 1877.

Nesse momento completam-se quase 10 (dez) anos de governo Conservador, pelo que se nomeia novo gabinete, desta vez liberal, dissolvendo-se a Câmara dos Deputados para possibilitar a maioria liberal na Câmara. Sendo assim, entre 1878 e 1885 , tem-se o retorno dos Liberais ao poder, dividindo-se em 07 (sete) gabinetes.

Em 1881, aprova-se a Lei Saraiva, que diminui o eleitorado brasileiro de $10 \%$ da população para $1,5 \%$ da população. Em 1885, é aprovada na Câmara dos Deputados a Lei dos Sexagenários, lei esta que causou muito desgaste no Partido Liberal para ser aprovada - a lei, de iniciativa do gabinete liberal, foi duas vezes rejeitada pela Câmara dos Deputados que era de maioria liberal. Para ser aprovada no Senado, fez-se necessário nomear novo gabinete, desta vez Conservador, com a consequente dissolução da Câmara dos Deputados:

Diante da impossibilidade do projeto ser aprovado no Senado, o Barão de Cotegipe assume em setembro de 1885. Após a aprovação, no Senado, da Lei dos Sexagenários - também conhecida como Lei Saraiva - Cotegipe - a Câmara dos Deputados é dissolvida, permitindo a Cotegipe ter maioria para governar. A atuação do chefe de Estado, como regulador da política fica clara ao arbitrar o processo de aprovação desta lei e, ao mesmo tempo, fazer a alternância de poder. (COSTA JÚNIOR, 2002, p. 135)

Sendo assim, entre 1885 e 1889 , retorno dos conservadores ao poder, dividindo-se em 02 (dois) gabinetes. Em junho de 1887, Dom Pedro II viaja para a Europa em um tratamento de saúde, tendo-se início, então, a Terceira Regência da Princesa Isabel. Exatamente na Terceira Regência é que se resolverá a chamada "Questão Servil”, que auxiliou na queda da monarquia no Brasil:

\begin{abstract}
Ainda faltava um golpe de morte na escravidão para a aprovação da Abolição. Em 28/02/1888, na capital do Império, ocorre a prisão arbitrária de um militar reformado. A princesa Isabel exige a demissão do chefe de polícia, mas o Barão de Cotegipe se nega a cumprir a determinação. Aproveitando-se deste pretexto, a Princesa Isabel demite o presidente do Conselho de Ministros e, por cerca de dois meses, chefiará a maioria e terá o monismo majoritário com hegemonia do chefe de Estado ao indicar o Conselheiro João Alfredo Corrêa de Oliveira (1835 - 1919) e exigir uma solução imediata para a questão servil (mencionada na Fala do Trono) e sem indenização em tempo recorde, aproveitando o clima da opinião pública favorável a tal decisão. Este desgaste político da Princesa Isabel, resultado da intervenção no Executivo, levará à perda da condição de estabelecer-se como chefe de Estado ao discutir-se a possibilidade de um Terceiro Reinado no Brasil. (COSTA JÚNIOR, 2002, p. 142)
\end{abstract}

Dom Pedro II regressa em 1888, sendo que, sobre a Lei Áurea, diz que "se estivesse no Brasil teria agido de maneira diferente, o que mostra a importância da forma de agir do chefe de Estado" (COSTA JÚNIOR, 2002, p. 143).

E por fim, em 07 de junho de 1889 formase o último gabinete do Império, com um retorno dos Liberais ao poder, presidido pelo Visconde de Ouro Preto. 
A forma por que se deu a edição da Lei Áurea e o consequente desgaste do sistema político levaram à deslegitimação do Poder Moderador como árbitro e regulador do sistema político brasileiro. Nestes últimos anos do Império, os embates entre Federação Centralismo transmutaram-se, também, no debate República (federação) e Centralismo (Monarquia e, consequentemente, o Poder Moderador), repetindo-se, em parte, os conflitos que levaram ao Ato Adicional de 1834. Nesse sentido, o gabinete do Visconde de Ouro Preto tentou cooptar os anseios federativos a fim de salvar a monarquia, no entanto, sem êxito ${ }^{43}$ :

- O sr. Coelho Rodrigues: - Verba volant, scripta manent. .- O sr. Visconde de Ouro Preto (presidente do conselho): Sim senhor (lê): 'Apresentando-me ao augusto chefe do Estado, Sua Majestade dignouse de dizer-me que tendo-se o nobre senador pela Bahia recusado a organizar ministério, resolvera encarregar-me dessa missão, desejando porém, antes disso, ouvir-me sobre a situação do país. Agradecendo tão alta prova de confiança respondi ao Imperador: Vossa Majestade terá seguramente notado que em algumas províncias agita-se uma propaganda ativa, cujos intuitos são a mudança da forma de governo. Essa propaganda é precursora de grandes males, porque tenta expor o país aos graves inconvenientes de instituições para que não está preparado, que não se conformam ás suas condições e não podem fazer a sua felicidade. No meu humilde conceito, é mister não desprezar, essa torrente de ideias falsas e imprudentes, cumprindo enfraquecê-la, inutilizá-la, não deixando que se avolume. Os meios de consegui-lo não são os da violência ou repressão: consistem simplesmente na demonstração prática de que o atual sistema de governo tem elasticidade bastante, para admitir a consagração dos princípios mais adiantados [...] Chegaremos a esse resultado, senhor, empreendendo com ousadia e firmeza largas reformas na ordem política, social e econômica,

\footnotetext{
43 "Na verdade, nada há que indique que o processo de mudança social em curso exigisse a instauração da República, ou seja, que ele não pudesse ter-se operado sob o signo do Império reformado, federalizado, na forma de uma "república velha coroada". É de bom alvitre lembrar que, como todas as monarquias do período, inclusive a britânica, o Império reformou o seu modelo político por pelo menos três vezes $(1834,1837,1881)$, e estava a ponto de operar a quarta, sob o Gabinete Ouro Preto, quando foi derrubado.” Em LYNCH, 2012, p. 283.
}

inspiradas na escola democrática [...] Portanto, conclui, a situação do país define-se, a meu ver, por uma fórmula - necessidade urgente de reformas liberais. [...] Determinou-me S. Majestade que positivasse com precisão quais as medidas que propor-me-ia a realizar para fazer face à situação. Observei que estavam compreendidas no programa aprovado pelo congresso do partido liberal [...] programa que tem como ideias capitais as que passava a enumerar: Alargamento do direito de voto [...] Plena autonomia dos municípios e províncias [...] Efetividade das garantias já concedidas por lei ao direito de reunião; liberdade de cultos e seus consectários [...] Temporariedade do Senado.

[... - O sr. Pedro Luiz: - É o começo da república. - O sr. Visconde de Ouro Preto (presidente do Conselho): - Não; é a inutilização da república. (OURO PRETO, 1891, p. 214-217)

Essa questão centralismo $\mathrm{x}$ federação, juntamente com s questões militar, a religiosa e o ressentimento dos grandes proprietários de terra culminaram no coup d'etat de 15 de novembro de 1889.

\section{CONCLUSÃO}

De todo o exposto, percebe-se que o poder do chefe de Estado e de Governo, no Segundo Reinado, confundiam-sem entre si, em certos períodos. Ou seja, não foi bem delimitado pela legislação da época e foi objeto de acalorados debates doutrinários, focados principalmente na atuação e limites do Poder Moderador, conforme São Vicente (1978) e Vasconcellos (1860). Porém, por força do costume, o poder do chefe de Estado sobre o Governo foi se restringindo com o passar do tempo, chegando ao ponto em que (excetuando-se a atuação da Princesa Isabel, durante a Terceira Regência) ele não mais interferia no governo, que ficava de jure sob sua titularidade, mas não de facto, sendo o Monarca mais um supervisor do que um chefe.

Assim, apesar de tal interferência no jogo político e mesmo nos atos do Poder Executivo, o Monarca não fazia aprovar, a seu bel-prazer, as leis que queria, mas detinha, sim, um poder de aconselhar, influenciar, por meio de pareceres, 
conforme o próprio Dom Pedro II atesta em carta endereçada à sua filha (PEDRO II, 1871). Embora não esteja positivada na legislação da época, essa posição do Imperador em não interferir nos atos do executivo a não ser em casos de ilegalidade ou a injustiça flagrante dos atos do Executivo veio-se firmando pelo costume durante os mais de 40 anos de Dom Pedro II como Chefe de Estado.

Apesar das fraudes nas eleições, a atuação do Poder Moderador e o costume que se estabeleceu permitiu que o Segundo Reinado, por meio de um Chefe de Estado imparcial (o que só se conseguiu devido ao fato de este não ser eleito), regulando e harmonizando os poderes Executivo, Legislativo e Judiciário, fosse um dos (senão o) períodos mais politicamente estáveis deste país, instaurando um sistema Parlamentarista que, apesar de não ser o modelo ideal, era adaptado à realidade brasileira da época.

\section{REFERÊNCIAS}

BASTOS, Aureliano Cândido Tavares. A Província: Estudo sobre a descentralização no Brazil. Rio de Janeiro: B. L. Garnier, 1870. Disponível em: <http://www2.senado.gov.br/bdsf/item/id/220526>. Acessado em: 12 set. 2016.

BRASIL. Decreto de 12 de novembro de 1823. Dissolve a Assembleia Geral Legislativa e Constituente e convoca outra Disponível em: $<$ http://www2.camara.leg.br/legin/fed/decret_sn/anterioresa1824/decreto-38881-12-novembro-1823568079-publicacaooriginal-91472-pe.html>. Acesso em: 09 set. 2016.

. Constituição Política do Império do Brazil. Rio de Janeiro: Conselho de Estado, 1824.

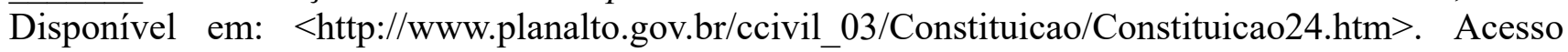
em: 09 set. 2016.

Lei de 12 de outubro de 1832. Ordena que os Eleitores dos Deputados para a seguinte Legislatura, lhes confiram nas procurações faculdade para reformarem alguns artigos da Constituição. Disponível em: <http://www.planalto.gov.br/ccivil_03/leis/LIM/LIM-12-10-1832.htm>. Acesso em: 21 set. 2016.

. Lei $n^{\circ} 16$ de 12 de agosto de 1834. Faz algumas alterações e adições á Constituição Política do Império, nos termos da Lei de 12 de Outubro de 1832. Disponível em: $<$ http://www.planalto.gov.br/ccivil_03/leis/LIM/LIM16.htm>. Acesso em: 21 set. 2016.

. Lei $n^{\circ}$ 105, de 12 de maio de 1840. Interpreta alguns artigos da Reforma Constitucional. Disponível em: <http://www.planalto.gov.br/ccivil_03/leis/LIM/LIM105.htm>. Acesso em: 21 set. 2016.

. Decreto $n^{\circ}$ 523, de 20 de Julho de 1847. Cria um Presidente do Conselho dos Ministros. Disponível em: <http://www2.camara.leg.br/legin/fed/decret/1824-1899/decreto-523-20-julho-1847560333-publicacaooriginal-83096-pe.html>. Acesso em: 29 set. 2016.

BRASIL. Assembléia Geral; Câmara Dos Deputados. Falas do Trono desde o ano de 1823 até o ano de 1889, acompanhadas dos respectivos votos de graças da Câmara temporária. Rio de Janeiro: Imprensa Nacional, 1889. Disponível em: <http://www2.senado.leg.br/bdsf/item/id/227319>. Acessado em: 13 set. 2016 
CABIESES, Amadeo Martín Rey. Consideraciones acerca de la utilidad y vigencia de la institución monárquica. Mar Oceana: Revista del humanismo espanõl e iberoamericano, Madrid, nº 27, 2010. Disponível em: $<$ http://ddfv.ufv.es/bitstream/handle/10641/580/Consideraciones\%20acerca\%20de\%20la\%20utilidad $\% 20 \mathrm{y} \% 20$ vigencia $\% 20 \mathrm{de} \% 201 \mathrm{a} \% 20$ instituci $\% \mathrm{C} 3 \% \mathrm{~B} 3 \mathrm{n} \% 20 \mathrm{mon} \% \mathrm{C} 3 \%$ A1 rquica.pdf? sequence $=1>$. Acesso em: 15 set. 2016.

CARVALHO, José Murilo de. D. Pedro II. São Paulo: Companhia das Letras, 2007.

CERQUEIRA, Marcello. Cartas Constitucionais: Império, República \& autoritarismo: ensaio, crítica e documentação. Rio de Janeiro: Renovar, 1997.

COSTA JÚNIOR, Luiz Roberto Guimarães da. Poder Moderador: O Quarto poder no Segundo Reinado (1840-1889). 2002. 233 f. Dissertação (Mestrado) - Universidade Estadual de Campinas, Instituto de Filosofia e Ciências Humanas, Campinas. 2002.

DORATIOTO, Francisco. General Osorio: A espada liberal do Império. São Paulo: Companhia das Letras, 2008.

FELONIUK, Wagner Silveira. Influências da Constituição de Cádiz na Constituição do Império do Brasil. In: XXVIII Simpósio Nacional de História, Lugares dos Historiadores: velhos e novos desafios, 2015, Florianópolis. Anais... Florianópolis: Anpuh, 2015, p. 1-15.

- A vigência da Constituição Política da Monarquia Espanhola de 1812 no Brasil: A Constituição de Cádiz e a pressão liberal popular. In: Giscard Farias Agra; Ricardo Marcelo Fonseca; Gustavo Silveira Siqueira. (Org.). História do Direito I. 1ª ed. Florianópolis: CONPEDI, 2014.

. A Instauração das Províncias no Brasil através da Influência Espanhola da Constituição de Cádiz. In: Giordano Bruno Soares Roberto, Gustavo Silveira Siqueira, Ricardo Marcelo Fonseca. (Org.) História do direito. $1^{\mathrm{a}}$ ed. Florianópolis: FUNJAB, 2014.

. Tecnicamente, a primeira Constituição do Brasil. Revista História e Cultura, Franca, v. 4, n.3, p. 204-233, dez. 2015. Disponível http://periodicos.franca.unesp.br/index.php/historiaecultura/article/view/1699, Acesso em: 04 fev. 2017.

FIGUEIRÊDO, Sara Ramos de. Da abdicação à lei de interpretação. Revista de informação legislativa, Brasília, v. 23, n. 11, p. 217-316, jul./set. 1986. Disponível em: $<$ http://www2.senado.leg.br/bdsf/item/id/181696>. Acesso em: 22 set. 2016.

FRANCO, Afonso Arinos de Melo. Estudos de Direito Constitucional. Rio de Janeiro: Editora Forense, 1957.

FRANÇA. Charte constitutionnelle $d u \quad 4$ juin 1814. Paris: 1814. Disponível em: $<$ http://www.conseil-constitutionnel.fr/conseil-constitutionnel/francais/la-constitution/lesconstitutions-de-la-france/charte-constitutionnelle-du-4-juin-1814.5102.html>. Acesso em: 20 set. 2016.

GONÇALVES, Mendes Roberto. O Barão Hübner na corte de São Cristóvão. Rio de Janeiro: MEC, 
1955.

GUANDALINI JUNIOR, Walter. O Poder Moderador: Ensaio sobre o debate jurídico-constitucional no século XIX. Curitiba: Editora Prismas, 2016.

JACQUES, Paulino. O sistema parlamentar como solução para a crise institucional brasileira. Revista de Informação Legislativa, Brasília, v. 15, n. 57, p. 5-10, jan./mar. 1978. Disponível em: < http://www2.senado.leg.br/bdsf/handle/id/181060>. Acessi em: 07 nov. 2016.

LIMA, Oliveira. O Movimento da Independência. O Império Brasileiro: 1821-1889. 2 ed. São Paulo: Comp. Melhoramentos de São Paulo, Indústrias de Papel, 1921.

LYNCH, Christian Edward Cyril. Entre a jurisdição constitucional e o estado de sítio: o fantasma do poder moderador no debate político da primeira república. Revista Brasileira de Estudos Constitucionais, Belo Horizonte, v. 6, n. 23, jul./set. 2012. Disponível em: $<$ http://bdjur.stj.jus.br/dspace/handle/2011/51681>. Acesso em: 08 set. 2016.

. O Poder Moderador na Constituição de 1824 e no anteprojeto Borges de Medeiros de 1933: Um estudo de direito comparado. Revista de informação legislativa, v. 47, n. 188, p. 93-111, out/dez. 2010. Disponível em: <http://www2.senado.leg.br/bdsf/item/id/198714>. Acesso em: 09 set. 2016.

. O Império é que era a República: a monarquia republicana de Joaquim Nabuco. Lua Nova, São Paulo, n. 85, p. 277-311, 2012. Disponível em: $<$ http://www.scielo.br/scielo.php?script=sci_arttext\&pid=S010264452012000100008\&lng=en\&nrm=iso>. Acesso em: 11 fev. 2017.

O Momento Monarquiano: o Poder Moderador e o Pensamento Político Imperial. Tese (doutorado). Defendido no Instituto Universitário de Pesquisas do Rio de Janeiro, IUPERJ, Rio de Janeiro, 2007.

MELLO FILHO, Flávio Antônio Rodrigues de. As atribuições do Imperador de acordo com a Constituição de 1824 do Brasil: análise dos poderes moderador e executivo. Cadernos de Iniciação Científica, São Bernardo do Campo, n. 11, 2014. Disponível em: <http://ojs.fdsbc.servicos.ws/ojs/index.php/CIC/article/view/96>. Acesso em: 09 set. 2016.

OURO PRETO, Visconde de. Advento da Ditadura Militar no Brasil. Paris: Imprimerie F. Pichon, 1891. Disponível em: <http://www2.senado.leg.br/bdsf/item/id/185628>. Acessado em: 15 nov. 2016

PEDRO II. D. Pedro II à Regente D. Isabel. Disponível em: $<$ https://idisabel.files.wordpress.com/2011/06/cartas-de-pedro-ii-a-princesa-imperial.pdf $>$. Acesso em: 27 out. 2016.

REBOUÇAS, Antonio Pereira. O Poder Moderador eficazmente defendido e a Monarquia Federativa combatida e profligada: Discurso pronunciado na Câmara dos Deputados na sessão de $1^{\circ}$ de setembro de 1832 sobre a discussão das emendas do senado ao projeto de reformas na constituição do Império. Rio de Janeiro: Typographia Universal de Laemmert, 1868.

SÃo VICENTE, José Antônio Pimenta Bueno, Marquês de. Direito Público Brasileiro e Análise da Constituição do Império. Brasília: Senado Federal, 1978. 
SCANTIMBURGO, João de. O governo colegiado de D. Pedro II e o governo unipessoal dos presidentes da República. Revista do Instituto Histórico e Geográfico Brasileiro, ano 160, n. 402, p. 187-206, jan./mar. 1999. Disponível em: <https://ihgb.org.br/publicacoes/revista-ihgb/item/127volume-402.html>. Acesso em: 19 nov. 2016.

SILVA, Carlos Medeiros. Evolução do regime federativo. Revista de Direito Administrativo, v. 39, p. 1-15, 1955. Disponível em: <http://bibliotecadigital.fgv.br/ojs/index.php/rda/article/view/14411>. Acesso em: 22 set. 2016.

SOUZA, Braz Florentino Henriques de. Do Poder Moderador. Ensaio de Direito Constitucional contento a análise do tit. V cap. I da Constituição Política do Brazil. Recife: Typographia Universal, 1864. Disponível em: <http://www2.senado.leg.br/bdsf/item/id/185585>. Acesso em: 21 set. 2016.

TÔRRES, João Camillo de Oliveira. A Democracia Coroada: Teoria política do Império do Brasil. $2^{\mathrm{a}}$ ed. Petrópolis: Editora Vozes Limitada, 1964.

VASCONCELLOS, Zacharias de Góes e. Da Natureza e Limites do Poder Moderador. Rio de Janeiro: Typographia de Nicolau Lobo Vianna e Filhos, 1860. Disponível em: $<$ http://www2.senado.leg.br/bdsf/item/id/224211>. Acesso em: 23 set. 2016.

Recebido em: 14/12/2016 Aceito em: 15/02/2017 
